\title{
FAITH AND FASHION: CHRISTIAN DRESS AND IDENTITY
}

\author{
by \\ Jacquline Angella Smith, \\ B.A., York University 2010, B.Ed., Brock University 2012 \\ A major research project \\ presented to Ryerson University \\ in partial fulfillment of the \\ requirements for the degree of \\ Master of Arts \\ in the Program of \\ Fashion
}

Toronto, Ontario, Canada, 2016

CJacquline Smith 2016 
I hereby declare that I am the sole author of this MRP. This is a true copy of the MRP, including any required final revisions.

I authorize Ryerson University to lend this MRP to other institutions or individuals for the purpose of scholarly research.

I further authorize Ryerson University to reproduce this MRP by photocopying or by other means, in total or in part, at the request of other institutions or individual for the purpose of scholarly research.

I understand that my MRP may be made electronically available to the public. 


\title{
FAITH AND FASHION: CHRISTIAN DRESS AND IDENTITY
}

\author{
Jacquline Angella Smith \\ Master of Arts 2016 \\ Fashion Studies \\ Ryerson University
}

\begin{abstract}
Christian women in Western societies are criticized about their manner of dress. The criticisms and debates address issues of "modesty" and "appropriateness," or a sense of "propriety." The apparel that is being designed, presented on the secular runways, and subsequently marketed hardly caters to Christian female consumers. This study seeks to answer the question: How do Christian women select, evaluate, and consume so-called modest and/or appropriate clothing in different socio-cultural contexts, particularly for church and other formal occasions? The study focuses on what is considered modest and appropriate clothing for Christian women. The perspectives of 10 Christian women were investigated and evaluated in a qualitative manner. A review of the literature indicates that there are concerns and issues surrounding this topic. Essentially, the purpose of the present research was to investigate and provide insight into how Christian women are expected to dress in a Westernized society; to determine what constitutes modesty and appropriateness for this specific demographic segment; and to analyze the experiences of Christian women in the process of obtaining modest apparel.
\end{abstract}

Key words: faith, fashion, dress, identity, modesty, appropriateness, Christianity, Christian women, Christian dress, Christian identity 


\section{Acknowledgments}

This Major Research Project (MRP) would not have been possible without the support of the MA Fashion Department, particularly Dr. Alison Matthews-David, Dr. Osmud Rahman and Dr. Kimberly Wahl. I am especially thankful to Professor Rahman my supervisor who worked patiently with me from submission of my proposal to the Research Ethics Board, providing me with sources and resources, recruitment of the participants, executing the interviews and transcriptions to the detailed editing, thoughtful comments and re-drafting to get my MRP completed and meeting the deadline. He provided me with invaluable intellectual support throughout my MRP journey. I am also grateful to my $2^{\text {nd }}$ Reader, Professor Wahl for her editorial assistance and feedback which has been invaluable. She was very diligent in editing my paper and giving valuable feedback. I appreciate the time they both took to see this paper to fruition within the timeline. I am also thankful to Mark Poulin for the time he took to review my work, particularly editing and formatting my citations and references. Last but not least, the participants. Without their volunteering to be interviewed, this project could not have been completed. 


\section{Table of Contents}

Page

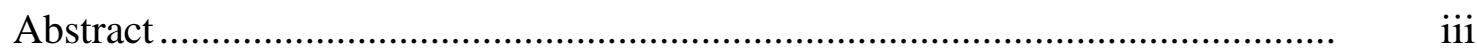

Acknowledgments................................................................................. iv

List of Figures ..................................................................................... vii

List of Tables ....................................................................................... viii

List of Appendices ................................................................................ ix

Chapter 1: Introduction ....................................................................................

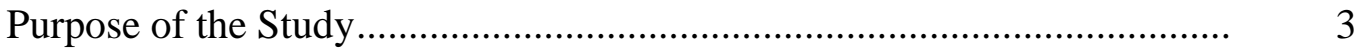

Significance of the Study ........................................................................

Theoretical Perspectives .........................................................................

Delimitations of the Study ........................................................................ 5

Chapter 2: Literature Review............................................................................. 7

Historical Background .........................................................................

Theoretical and Conceptual Framework ...................................................... 10

Defining modesty ………………………………………….....

Symbolic meanings of modesty ....................................................... 11

Fundamental Teachings ........................................................................... 13

Christian identity .......................................................................... 13

Dress and adornment - situations and appropriateness ..................... 16

Faith and Fashion ...............................................................................

Summary ................................................................................. 20

Chapter 3: Research Methodology................................................................ 22

Research Sample .......................................................................... 22

Ethical Considerations ......................................................................... 23

Interview Design and Questions............................................................... 24

Recruitment and Interview Setting ...................................................... 25

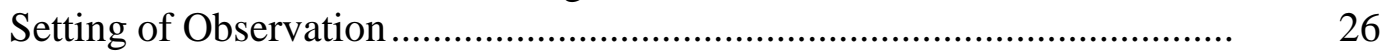

Analytical Method ............................................................................ 26

Chapter 4: Research Findings/Analysis .............................................................. 28

Importance of Fashion ............................................................................ 28

In-Depth Interviews............................................................................... 29

Fashion knowledge/consciousness.................................................... $\quad 30$

Shopping behaviour/patterns for clothing......................................... 31

Christian identity versus personal identity .......................................... 32

Appropriate and modest attire........................................................... 34

Perceptions of modesty, appropriateness, and personal style ............ $\quad 35$

Observation...................................................................................... 37

Church no. 1 ....................................................................... 37

Church no. 2..................................................................... 38

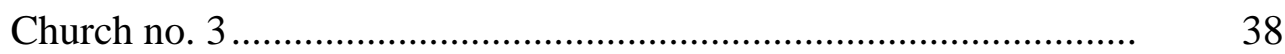

The Fashion Industry ............................................................................ 
Chapter 5: Discussion and Conclusions...................................................... 42

Summary of the Study ..............................................................................

Limitations of Study .........................................................................

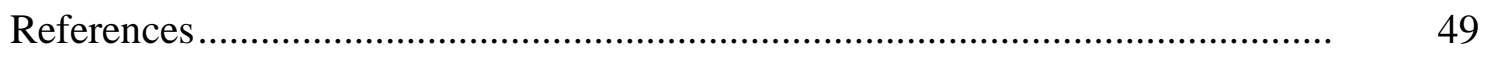

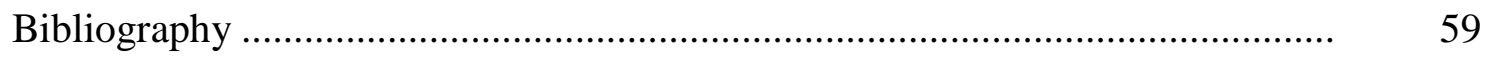




\section{List of Figures}

$\begin{array}{ll}\text { Figure } & \text { Page }\end{array}$

1. Gospel singer Erica Campbell in white turtleneck, long sleeve dress ............. 15

2. Dolce \& Gabbana religious iconography fashion show .................. 18

3. The first Christian Fashion Week ......................................................... 20

4. Perceptions of modesty and appropriateness ........................ 36 


\section{List of Tables}

$\begin{array}{lll}\text { Table } & \text { Page }\end{array}$

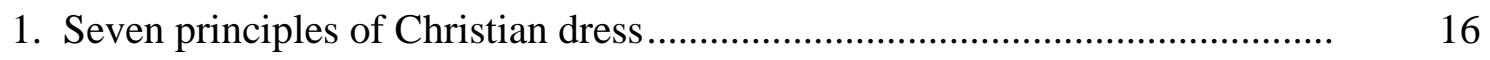

2. C.A.R.E. Model ................................................................................ 20

3. Participants' profile........................................................ 29 


\section{List of Appendices}

$\begin{array}{ll}\text { Appendix } & \text { Page }\end{array}$

A: RYERSON ETHICS BOARD APPROVAL ...............................................

B: INTERVIEW QUESTIONS ................................................................ 46

C: RECRUITMENT POSTER ……………………………………......... 48 


\section{Chapter 1}

\section{Introduction}

We are living in an age where the individual self is being expressed mainly through clothing and fashion identity (Craddock, 2012; Shete, 2012). There is heightened freedom of self expression and individualization in the 21 st century, particularly in dress and adornment, influenced by the media, iconic celebrities, and the fashion industry. This type of freedom is creating havoc not only within Christian communities, but within other religious communities as well. Public debates span across issues of liberated women in Western society versus oppressed women in other religions and cultures (Wade, 2012). There are growing concerns and discourse on modesty among Christian communities (e.g., see Bacchiocchi 1995; Blair, 2014), while in the Muslim/Islamic communities, religious dress and adornment is being challenged by young women - costing them their lives (Spencer, 2010). In addition, the fashion industry creates commodities of religious ornaments and symbols (King, 2015; Macmillan, 2013; wbauck, 2013) in an effort to bring faith and fashion together on the runway (see chapter 2, Figure 1).

The fact is, most Western societies have inherited a Christian heritage from early missionaries. However, the lines of Christianity are being blurred as personal and fashion identity takes precedent over a Christian identity. Thus, Christian women are seemingly being confronted with criticisms and debates about their manner of dress and adornment (Blair, 2014). The criticisms and debates specifically address issues of modesty and appropriateness, or a sense of propriety. It appears that there are certain implicit expectations when it comes to professed Christian women (Bacchiocchi, 1995; White, 1862, as cited in Robinson, 1950/1999), because there are no clear guidelines or dress codes to adhere to. Dressing modestly or 'modest dress' 
within the Christian context refers to dress and adornment that does not appear 'sensual' (Bacchiocchi, 1995; Blair, 2014)

The main concern being faced by Christian communities is that the worldly fashions are creeping into the church (Chen, 2012), causing men to lust and sin (Gilkerson, 2013; Spinney 2010). Ministers and church leaders often warn Christian women against following the 'indecent' fashions of the world, challenging them to separate themselves from women of the world and dress accordingly (Bacchiocchi, 1995; Blakesley, 2010). Thus, the immodest influences within the current fashion system and among iconic celebrities are having a negative impact on Christian churches, primarily among the youth. Red carpet fashions set the trends in promoting and showing off the outer body — the self, while concealing inner beauty — the heart. In religious discourses on dress and adornment, the debate is that it is a matter of the heart (Riggs, 2009).

According to a demographic study conducted by Pew Research Center (2011), Christians represent nearly a third of the global population. In Canada, $67.3 \%$ of the population is affiliated with a Christian religion (Statistic Canada, 2014), while in the United States, $70.6 \%$ represents Christianity (Pew Research Center, 2016). Yet, most of the apparel being designed, showcased on the secular runways, and subsequently marketed to consumers hardly caters to the market segment of Christian women seeking modest apparel. With such a gap in the current consumer market for modest apparel, and the irrepressible issues of immodest influences, the question posed and explored in this research study is: How do Christian women select, evaluate, and consume modest and/or appropriate clothing in different socio-cultural contexts, particularly for church and other formal occasions, such as weddings and banquets? 


\section{Purpose of the Study}

Essentially, the purpose of this research study is to investigate and provide insight into how society (in general) expects Christian women to dress; to determine what constitutes modesty and appropriateness for this specific demographic segment; to analyze the experiences Christian women encounter in finding modest and appropriate apparel; and to explore the perspectives of Christian women and their understanding of modest dress. As such, a critical analysis of the literature has been presented to determine the impact of the issues of modesty on this research segment and population and to highlight and/or recommend solutions to this perceived problem within the Christian community. The study will also add to the repository of academic discourse on the topic of Christian dress and identity. For the purposes of this research study, Christian women were recruited from various Christian denominations (Catholics, Baptist, Methodist, Seventh-Day-Adventist, Church of God, Anglican, etc.) but women of other religions were excluded from the present study.

\section{Significance of the Study}

In addressing these research questions, objectives include: providing information and insight into Christian dress and identity; educating Christian women about the impacts, expectations, and importance of modest dressing within the Christian church community; establish that Christian women can dress modestly and fashionably without sacrificing their Christian values/beliefs; support an argument that Christian women do not have to conform to the current fashion system, but that they could develop their own based on principles identified. This study can provide important insights and qualitative data to both academic contexts and the fashion industry including the attention to these issues, needs and concerns of this market segment, and how their needs can be met more effectively. Thus, it is important to examine this 
research topic because Christian women make up a large portion of the world's population (The Global Religious Landscape, 2012) and also a significant share of the apparel market.

\section{Theoretical Perspectives}

The literature review drew on the social, psychological, and theological aspects of modesty, appropriateness and Christian identity. From the sociological viewpoint, Christians are expected to portray modesty in their dress and adornment. If not, they are looked on in shock/dismay, criticized, and ridiculed within and beyond the church (Blair, 2014). Psychologically Christian women struggle with their personal and Christian identity while living in a world bombarded with fashion and beauty ideals (Kite \& Kite, 2015). This simply means that one cannot pretend to be a Christian because if one dresses according to worldly fashion ideals, this will display what is evidently in the heart and mind - the need to portray the 'self'. (Bacchiocchi, 1995). The Apostle Paul also cautioned Christians not to conform to this world (Romans 12:2). Therefore, the sociological effect and implication is that they will be judged outwardly (Sermon Index, 2015) based on their appearance.

Many theologians and dress reformers (e.g., Bacchiocchio, 1995; Spinney, 2010a, 2010b, 2010c; White, 1862, as cited in Robinson, 1950/1999) tend to rely on the biblical teachings of the bible and its apostles. Many of them base their arguments on 1Timothy 2:9 and develop principles for today's applications. Although the Apostle Paul was addressing the adornment issues in his time, when secular practices seemed to be taking over the church, a similar concern is being expressed today by contemporary ministers and biblical scholars. According to these ministers or theologians (Aslop, 2010), the world is creeping into the church, referring to immodest dressing and adornment of professed Christian women. The problem is, Christian women, particularly in Western societies, are bombarded with images of a secular ideal, which 
tends to appeal to the human nature, which is the need to feel and look beautiful (Gill 2006;

Mackinney-Valentin, 2013). With such perspective, the in-depth interviews and observations were conducted to investigate and highlight these social, psychological and spiritual implications. Thus, in-depth interviews helped to gain a deeper understanding of how Christian women feel about beauty ideals with regards to their personal and/or Christian identity.

\section{Delimitations of the Study}

There are many prior studies which have examined religion, religious clothing or vestitures, and women's adornment in other religions, however, they do not quite fit the focus of this study on Christian women in a Westernized society. The current study was only focused on Christian women of various Christian denominations (Catholics, Baptist, Methodist, SeventhDay-Adventist, Church of God, Anglican, etc.) and non-Christian women were excluded. The rationale for this delimitation is that other religions have specific modes of dress and adornment, some of which are culturally adhered to and enforced while others are religious vestments and habitual attire. For instance, Muslim women dress in a peculiar fashion that identifies them as Muslims regardless of their geographical location, as opposed to Christian women in a Westernized society not having a specific dress code and thus being influenced by the secular fashion industry. Various religious websites and blogs (such as: chapellibrary.org; trendhunter.com; hungertv.com; to name a few) extensively debate on the issues of modesty in dress, which indicate the growing concerns about dress and identity among Christian women in Western societies. This research provides awareness of the issues associated with modesty in general and specifically within the Christian churches and communities; the impact it has on Christian women and their identity in a society influenced by secular fashion ideals; the 
importance and benefits of dressing modestly; and how to acquire modest and appropriate apparel for various occasions. 


\section{Chapter 2}

\section{Literature Review}

Throughout this research study Christian women are viewed within the context of a Western culture where Christianity is a dominant religion (Pew Research Center, 2012; 2014) and many women can freely express their individual self through their clothing (Arthur, 2016; Entwistle and Wilson, 2001; Evans, 1989). The literature review indicates however, that there are concerns and issues surrounding the topic of Christian dress and identity. The focus was narrowed on modesty and appropriateness in dress and adornment. Many prior studies critically analyse and report different perspectives and perceptions of Christian attire by different writers such as bloggers, ministers and other religious opinion leaders. However, academic literature on "faith and fashion" (Shalit, 1999) is sparse. Most of the academic literature are primarily focused on religious/ceremonial dress (Bailey, 2013; Summerfield et al., 1999) and Islamic clothing (Afshar , 2006; Hume, 2013; Lewis, 2011, 2013; Tarlo, 2010), which indicates that not much academic research has been done in this area. There are a number of religious websites and blogs (e.g., christianitytoday.com; vice.com; purefashion.com; model4jesus.com; unwrinkling.com) which have discussed and/or debated on concepts of modesty and appropriateness.

Through these various lenses, the issues being debated demonstrate the relative and subjective nature of the concept of modesty and appropriateness as it relates to Christian dress and identity. Reproach has been cast at different angles: (1) practitioners in the fashion industry often focus on the sexual attraction of clothing rather than modesty (Harmon, n.d., Part II, para. 6); (2) Christian men have the responsibility to help their wives and daughters to dress modestly (Alcorn, 2016; Spinney, 2010a); and (3) Christian women are expected to be faithful witnesses for Christ through their clothing according to the holy scriptures (Sermon Index, 2016). 
Nevertheless, in reviewing and analysing the literature, there seems to be a consensus on the growing concern of immodest clothing among Christian women. A compilation of articles (e.g. Aslop, 2010; Pollard, 2010a, 2010b; Spinney, 2010a) published by Chapel Library have addressed these concerns.

The literature examines several factors impacting modesty, such as an emphasis on moral decline or immorality (Spinney, 2010b); focusing on individual self, socio-cultural practices, and fashionable trends (Bunyan, 2010; Pollard, 2010a); establishing principles in Christian dressing (Bacchiocchi, 1995; Chen, 2012), balancing outer beauty and inner beauty (Kite \& Kite, 2015), and evaluating personal and Christian identity through dress (Baxter, 2010). However, throughout the literature reviewed (i.e., theological and popular cultural sources) the methods used to explore issues of modesty are based mainly on biblical teachings and ethnographic observations. As a result, the Bible was chosen as the foundation for this review as it is considered a key source in relation to principles of Christian dress and identity. Authors including Samuel Bacchiocchi, a theologian and professor at Andrews University, have given guidance and principles on modest and appropriate dressing, all referring to 1Timothy 2: 9-10 in the Bible.

\section{Historical Background}

Schmidt (1989) sets the tone with a historical background of religious expectations in 'proper dress'. This literature focuses on the sumptuary laws of the 19th century, which stipulated the appropriate dress for each hierarchical rank. According to Schmidt, during this period, clothes began defining gender and familial role, proper dress was required to reinforce the inherently virtuous nature of religious women. The Bible, considered a book which includes sumptuary laws (Bacher \& Dembitz, 2011), states that "women should adorn themselves in 
modest apparel, with shamefacedness and sobriety; not with braided hair, or gold, or pearls, or costly array; but (which becometh women professing godliness) with good works" (1 Timothy 2: 9-10).

Theologians, such as Bacchiocchi (1995) and various authors (e.g., Alsop, 2010; Baxter, 2010; Bunyan, 2010) make reference to this 1 Timothy 2:9-10, in addressing the issues of Christian dress and identity. This Bible passage is considered a sumptuary command based on the period and context in which it was written (The International Bible Society, 2014). During this period (1350s), women began to feel a sense of freedom in their dress and individual identity/self (Breward, 1995: pp. 32-34). Also, they used fashion to show off their wealth, and so many would adorn themselves in fine clothing, jewellery, braided hair, and more. The problem was, this attitude (from the secular/pagan) society crept into the church as Christians, particularly women, began to dress extravagantly and/or immodestly in styles of dress and adornment. This is the reason why Peter reminded the female believers, "Your beauty should not come from outward adornment, such as elaborate hairstyles and the wearing of gold jewelry or fine clothes. Rather, it should be that of your inner self, the unfading beauty of a gentle and quiet spirit, which is of great worth in God's sight. (I Peter 3:3-4, New International Version)." This phenomenon was seen as an apostasy of the church and so the Apostle Paul, considered a minister/apostle counselled against this kind of dressing where it was becoming an adornment of the self, which according to Bacchiocchi (1995) proved that there were (ungodly) issues going on in the hearts of Christian women.

In addition, this concern also stemmed from the problems in the 1800 s, where women's dress styles were affecting their health and mobility (Bellatory, 2015). Protestant Reformers such as Ellen White and Amelia Bloomer condemned the use of extravagant clothes and ornaments 
and promoted dress reform styles, characterized by simplicity and modesty (White, 1862, as cited in Robinson, 1950/1999). The body shapes of women were distorted, and their hips were overloaded with heavy skirts dragging and sweeping the ground (Breward, 1995). As a result, in many countries, sumptuary laws were passed giving detailed descriptions on how Christians should dress themselves (Brundage, 1987). Nowadays, the weight of a woman's clothing is a fraction of what it used to be. However, the dress reform was about concerns for health rather than modesty. Nevertheless, today the issue has moved from the standpoint of health to one of modesty in dress.

\section{Theoretical and Conceptual Framework}

Interpretative theories, primarily symbolic interaction, have been explored to demonstrate how dress has played a crucial role in reflecting and helping to construct social and personal identities of Christian women. The theories of "symbolic interaction" (Blumer, 1986; Kaiser et al., 1991) and "labelling" (Ash, 1999; Becker, 1991) support the biblical principles/teachings of modesty and appropriateness in dress and identity, as a Christian woman would aspire to dress in a manner that portrays the identity or character of a Christian. Symbolic interaction explains certain aspects of human behaviour and/or symbolic meanings of objects/imageries/actions (Flynn \& Foster 2009; Kawamura, 2011) in different situational contexts. For instance, meanings are attached to modes or style of dressing that would identify/differentiate a Christian from a non-Christian. "A symbolic interactionist approach to appearance management offers a nexus of concepts that are vital to identity construction: agency, emergent meanings, and negotiation (Freitas et al., 1997: p. 324)." Labelling theory, on the other hand, focuses on the social reaction or criticisms that a Christian woman would probably receive if seen dressed provocatively. This is because "labelling theory is concerned with how the self-identity and behaviour of an 
individual is influenced by how that individual is categorized and described by others in their society" (Sociology Index, 2002, para 2). Both theories are closely related, and take into consideration the view that people often create their realities through different interpretations and meanings of objects, imageries and actions. This process can be applied to fashion and clothing as well (Kawamura, 2011). Nevertheless, understanding the perspectives of Christian women in a qualitative approach with these interpretative theories is important and useful to illuminate what role clothing has played in reflecting and helping Christian women to construct their social and personal identities.

Defining modesty. The term or concept of "modesty" is not easy to define. According to the Merriam-Webster Dictionary, modesty is "the quality of behaving and especially dressing in ways that do not attract sexual attention" (“Modesty," n.d., para. 2). In a similar vein, modesty is also referred to a character trait involving some type of virtuous self-assessment (McMullin, 2010). Stone (2014) argued that "what is considered 'modest' (or not) depends on your social and cultural context”. According to Stone (2014) and Gresh (2002), many Christian communities, for example, might find Christian women wearing hip-slung jeans, skin-tight Tshirts and makeup are inappropriately dressed. For the sake of this research, modesty is being defined as dressing and adorning one's self in ways that do not attract lustful and sexual attention to the body. However, the word "modest" may carry different meanings to different people in different cultures.

Symbolic meanings of modesty. In a westernized culture, modesty may carry different symbolic meanings among individuals. For instance, it could be used to create a social and personal image and identity, to express the self, as well as to imitate and display a godly character and Christ-like identity. According to a study of self-esteem in a collectivistic culture 
(Du \& Jonas, 2015), modesty is a kind of social norm that guides or constrains people's social behaviour. The literature has shown that modesty in dress has had important symbolic meaning in various religions (Mormons, Amish, Muslims, and more). According to the Mormons/Latter Day Saints, modesty in dress protects the purity and moral values of their youth (Blakesley, 2009). In this case, the symbolism of modest dress is linked to purity. The view is that immodest dress could lead to immoral and unchaste behaviour. Women were responsible if their manner of dress caused males to fall in sin (Spinney, 2010a). Therefore, modesty is used as a shield against sexual temptation (Blakesley, 2009). In addition, the human nature is to show off the self, which is usually depicted in our bodies and manner of dress (Ashworth, 2012). As such, our self-image and self-worth is expressed in our dress or deportment. For women, our dress tends to show to society the value we place on ourselves or our (outer) body (Kite \& Kite, 2015). It demonstrates the extent to which we would like to look and feel beautiful. Likewise, modesty in dress can be viewed as a sign of self-image, personal style, or identity. Christian women should choose and depict their character, whether it is a godly or worldly character. As 1 Corinthians 6: 19-20 stated, "Do you not know that your bodies are temples of the Holy Spirit, who is in you, whom you have received from God? You are not your own; you were bought at a price. Therefore honor God with your bodies." From a Christian perspective, it is reasonable to suggest that modesty is a manifestation of a godly character. A godly character also reveals "inner beauty"the heart, as we are judged outwardly — in our manner of dress and adornment. According to biblical teaching, a Christian should consider to take on a Christ-like identity, for example:

Your beauty should not come from outward adornment, such as elaborate hairstyles and the wearing of gold jewelry or fine clothes. Rather, it should be that 
of your inner self, the unfading beauty of a gentle and quiet spirit, which is of great worth in God's sight. (1Peter 3: 3-4)

\section{Fundamental Teachings}

Christian identity. According to the Bible (Romans 12:2; 1Peter 2:9; 1Peter 3:3-4),

Christians should take a different approach to their lifestyles and outward appearance instead of trying to fit into the ideal of feminine beauty or conforming to the current fashion system. Some fundamental teachings such as 1 Samuel 16:7 stated that "But the LORD said to Samuel, 'Do not consider his appearance or his height, for I have rejected him. The LORD does not look at the things people look at. People look at the outward appearance, but the LORD looks at the heart."' With these biblical teachings, Bacciocchi (1995) asserts that clothes do not make a Christian, but Christians reveal their identity through their clothes and appearance. Based on these scriptures of dress and adornment, he outlined several principles for Christians to follow. The author argues that it takes courage to "distinguish between the capricious mode that changes and the sensible style that remains. ... Our outward appearance is a constant silent witness of our Christian identity" (1995, p. 128). These arguments suggest that Christians are expected to dress in a manner that distinguishes them from the secular world as though giving/showing a testimony in their dress and adornment.

Dress and appearance are considered to be important factors in our social, profession and/or individual lives. Therefore, dress and appearance should also be important factors in a Christian's life (LDS Church, 2016). In listening to a Youtube presentation of Christian Dress and Adornment delivered by Bacchiocchi (2008), he does not deny the importance for Christian women to dress and look fashionable in a contemporary society. However, he counsels against overdoing such as following or trying to keep up with the fashion trends/fads where the focus 
becomes the self and not the salvation of souls. Thus, it is important to note that the principles presented in the bible and expounded on by Bacchiocchi (1995) and other religious authors were used as a guide to qualitatively analyze materials in this research study.

White (1862, as cited in Robinson, 1950/1999) in The Review and Herald, was not advocating for Christian women to abandon fashion/dress, but to abandon the vanity it creates in the heart. For instance, in her days (19th century), the clothing people worn could reveal their status in life. As Breward (1995) demonstrated in his book, many servants/peasants wanted to live like the aristocrats very much like how today's (poor) society craves the lives/lifestyles of the rich/celebrities. Even the colour of the garment told a lot about the wearer (Breward, 1995: pp. 17, 32). According to Robinson (1950/1999), Ellen White wrote a lot about dress reform because she recognized that the outward appearance was making a statement about the identity of Christians, and that their dress should be in accordance with their faith. The problem was, and still is, that Christian women are dressing in immodest fashions and it is difficult to identify them as Christians. Bacchiocchi (2008) argues (in a video presentation) that, "modern dress fashions reject reverence and respect as the basis for constructive human relations. Its concern is to sell its products by exploiting the sex drive of the human body, even if it means marketing indecent clothing." This is the type and power of influence that the secular fashion system has on Christian women, which seems to be a major concern among the Christian community, something ministers/theologians have pointed out in their works published by Chapel Library.

Nevertheless, the criticisms encountered on Christian fashion blogs and in the sermons of ministers surrounding Christian dress and adornment are very subjective arguments. One gospel artist, Erica Campbell, was chicly clad in a long sleeve turtleneck and mid-calf length dress-all covered up (see Figure 1 below). However, she was criticized for dressing immodestly, as all her 
curves were accentuated by the form-fitting fabric and style of the dress (Blair, 2014). While Christian fashion blogs and sermons give insight into how women within the church communities feel and the pressure they experience in portraying a personal and/or Christian identity, the interviews in this qualitative research provide further insights as well as methods into ways of finding out first hand, the perspectives and relative concept of modesty and appropriateness from Christian women's points of view.

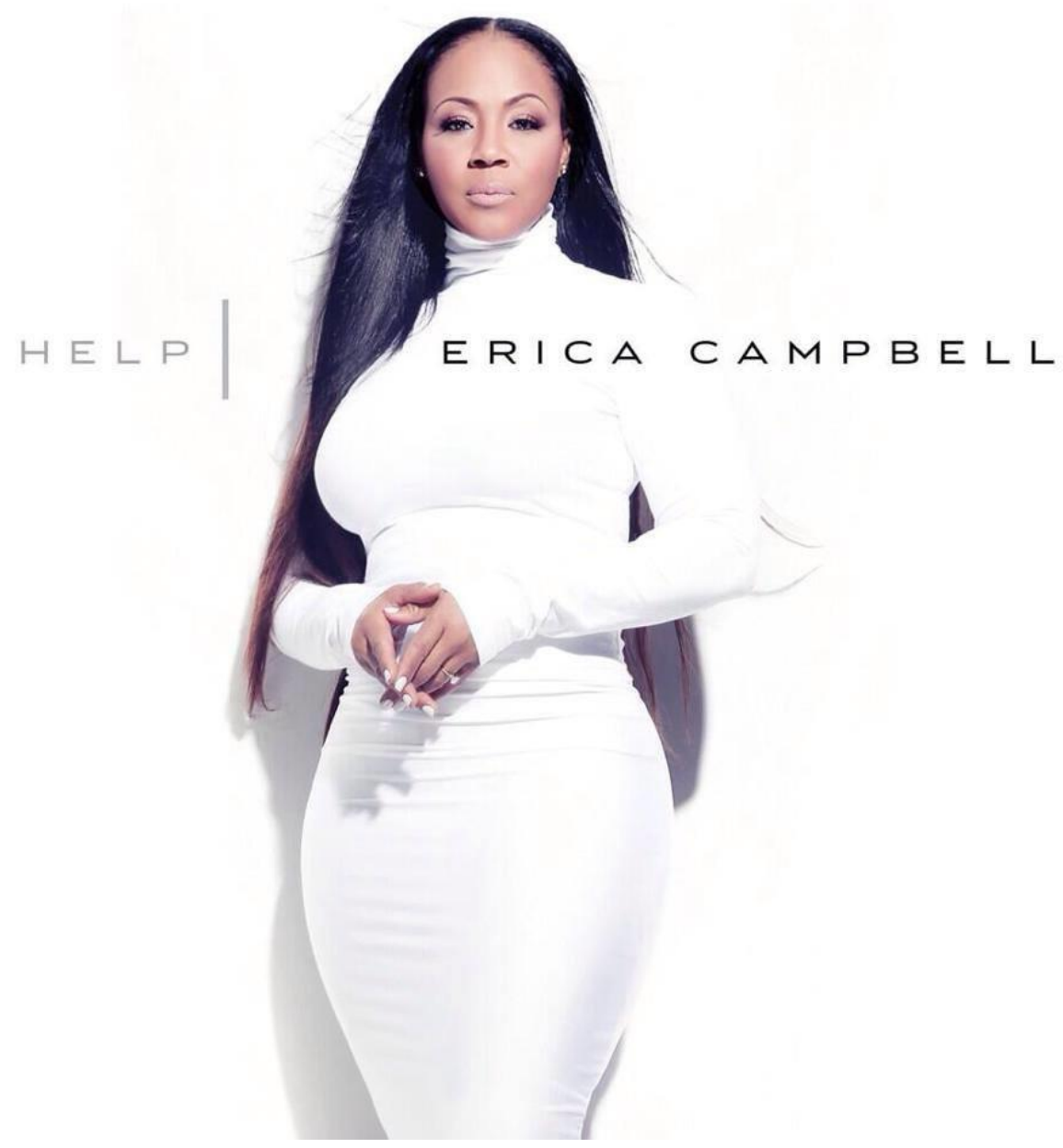

Figure 1. Gospel singer Erica Campbell in white turtleneck, and long sleeve dress. Source: Blair (2014). 
Dress and adornment - Situation and Appropriateness. According to Kayser (2009), "...the scripture put expectations upon believers as to how they should think, talk and live" (p.2). Like Bacchiocchi, (1995), Kayser argues that a person's outward appearance communicates (and often miscommunicates) very loudly, and that the body must be disciplined to communicate consistently with verbal communication (Kayser, 2009). This suggests that Christians should be living/dressing to reflect what they are speaking/teaching about their beliefs. Kayser further asserts that, "...just as there is body language that communicates and miscommunicates, there are clothing issues that communicate or miscommunicate (2009:7). For instance, it would not be appropriate to go to a wedding in "mourning apparel" (2 Samuel 14:2), just as it would be inappropriate to go to a construction job in a tuxedo (Kayser, 2009:7). These arguments present the apparent expectations that Christian a woman should dress in a different manner-especially for church. Kayser (2009) presents a variety of scripture verses that describe clothing for different individuals or specific occasions (royal attire, noblemen, scribes, prophets, prisoners, warriors, widows, weddings, prostitutes, and modest apparel). This indicates that there is prescribed clothing that is appropriate for each occasion and that there is a time and a place to wear certain types of garments.

Bacchiochhi (1995) outlines seven principles that a Christian woman should consider in dress and adornment, as show in Table 1.

\section{Principles of Christian Dress}

1) Dress and appearance are an important index of Christian character;

2) Adorning our bodies with colourful cosmetics, glittering jewelry, and luxurious clothes reveals inner pride and vanity, which are destructive to ourselves and to others;

3) To experience inner spiritual renewal and reconciliation with God, it is necessary to remove all outward besetting objects of idolatry, including jewelry and ornaments; 
4) Christians should dress in a modest and decent way, showing respect for God, themselves, and others;

5) Christians should dress soberly, restraining any desire to exhibit themselves by wearing eye-catching clothes, cosmetics, or jewelry;

6) Wearing finger rings is not compatible with the bible principles of modesty; historically, they have tempted people to wear all kinds of jewelry; and

7) Christian should respect gender distinctions in clothing by wearing clothes that affirm their male or female identities.

Table 1: Seven principles of Christian dress (Bacchiochhi, 1995)

One Christian denomination (Seventh-Day-Adventist) relies steadfastly on the teachings of the Bible in 1Timothy 2:9, as well as the principles set out by Bacchiochhi (1995) and White (1862, as cited in Robinson, 1950/1999). Members of this religious organization do not adorn themselves in jewellery except that some members choose to wear a wedding band or a watch. They follow the teachings of founder or pioneer Ellen G. White on dress reform in the 1800s. Bacchiocchi also supports White's teachings on dress reform, which came about as a result of the effects women's dress styles were having on their health and mobility, which prompted an outcry by women advocates such as Ellen White and Amelia Bloomer for a reform in dress practices (Moving Towards Modesty, 2010; Robinson, 1999). However, the issue moved from the standpoint of health to one of simplicity in dress. Today the concern is about modesty, and according to Bacchiochhi (1995), "modesty and decency are out, and nudity and sensuality are in" (p. 124).

\section{Faith and Fashion}

There is controversy and debates surrounding fashion inspirations or religious iconography on the "secular" runways, as there are no concerns for the values or beliefs or sacredness in religious dress/imagery (Bayas, 2009). Lourdes Sanchez Bayas (2009) talks about 
the clashes between religious and secular values, with the use of religious iconography, seen particularly in a Dolce \& Gabbana runway display of the crucifix. She makes the claim that fashion designers are seeking to transform lives through the arousal of passion through religious references such as the use of the crucifix and rosary beads as necklaces. This speaks to the degradation of religious values and beliefs by the fashion system. Religion is being introduced on the runway in an effort to undermine the solemnity or sacredness of the practice and thus decency in dress and adornment, which in effect will tarnish the Christian identity. This indicates that a secular runway compromises the true identity of a Christian. As such, there is bound to be controversy and debates on such fashion inspirations on the secular runways. King (2015) argues that there is no concern for the values or beliefs or sacredness in religious dress/imagery. The runway show (illustrated in Figure 2) presents itself as a mockery to Christianity or religion for that matter. The fact is, both secular and Christian values cannot co-exist in the same environment.

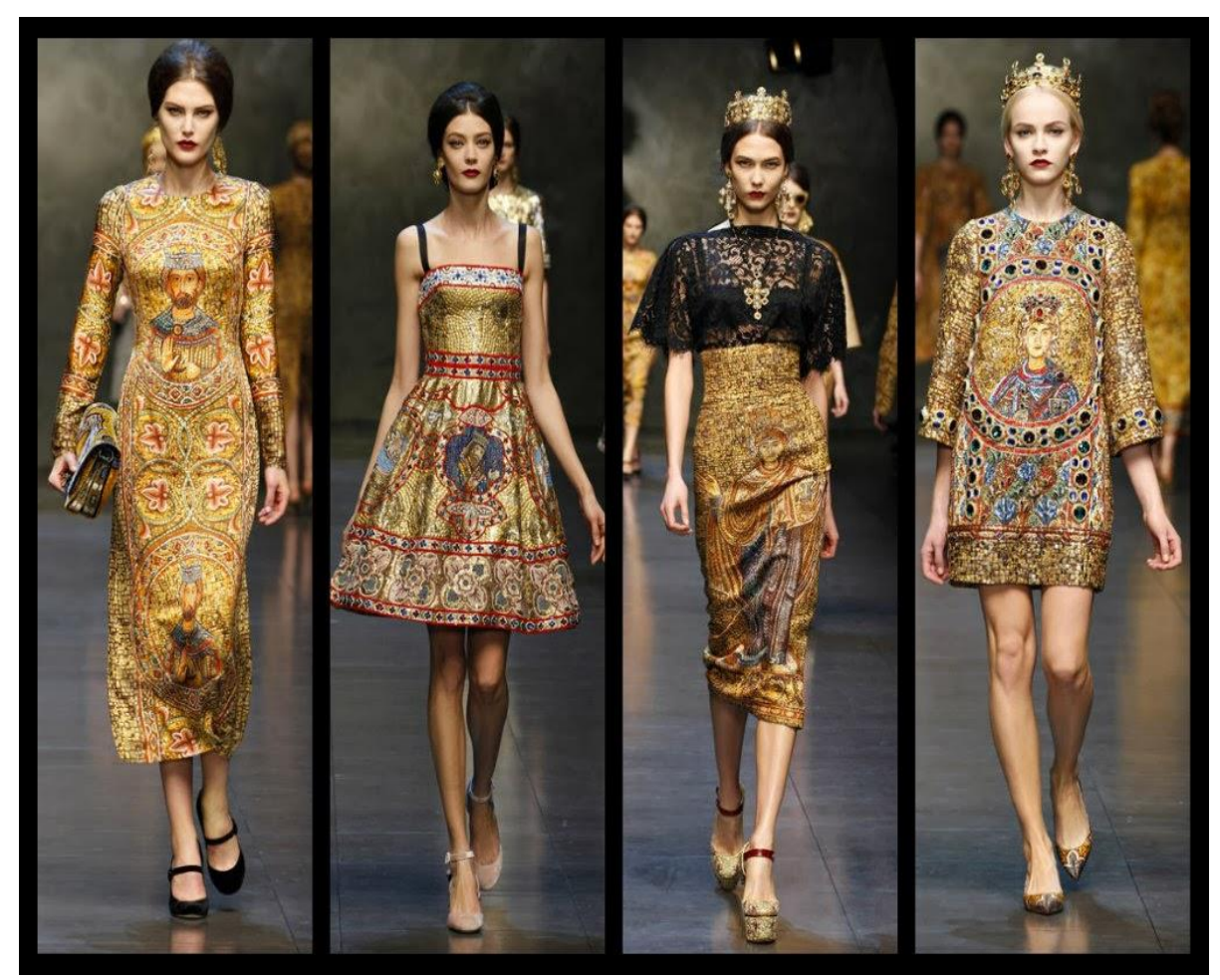


Figure 2. Dolce \& Gabbana religious iconography fashion show. Source: Mackay (2013).

The problem is, according to Carlin (2013) who is a blogger on the topic of faith and fashion, the history of fashion has been influenced by religion, but it seems fashion and religion will continue to collide (Carlin, 2013), meaning there will be constant debates on faith and fashion - particularly on the immodest influences on the secular runways that are creeping into Christian communities. The images of fashion ideals are bombarding youth who are struggling with finding their identities (personal, fashionable, and spiritual). The media, in addition, supports these ideals as they are showcased in programs such as the Red Carpet and other Hollywood awards events. Celebrities compete for the most skin or the least fabric in their attire, while fans aspire to look like their favourite star.

On a positive note, modest fashion or clothing is becoming a trend in the world of high fashion, propelled particularly by young designers influenced by their faith (Dallas, 2014). Lewis (2011) acknowledged that there is a growing trend in the "modesty market" and that it is not only supported by women of the Islamic and Judaism faith, but also Christian women who are motivated to dress modestly. These faith groups are combining modest dress with mainstream fashion styles and shapes, and the Internet is becoming a popular source for fashionable solutions to modesty requirements.

However, there is no consensus among these faith groups on dress code or policy although there are considerable debates within each faith on how modesty should be expressed. These arguments support the idea that Christian women should develop their own fashion system, to avoid compromising their Christian values and beliefs or the sacredness of their religion. Due to the growing concerns of Christian women (Bauck, 2015; Gresh, 2002; Shalit, 2000; Whelchel, 2005), Christian Fashion Week (CFW) was founded by Jose Gomez, Mayra 
Gomez, Wil Lugo and Tamy Lugo, and the first CFW event was held on February $8^{\text {th }}$, 2013. In the following year, the ChristianRunway.com was launched. In 2015, CWF even broadened their platform beyond modestly, and developed a new ethical and sustainable model labelled "CARE" (Bauck, 2015: 78, see Table 3).

\begin{tabular}{|l|l|}
\hline \multicolumn{2}{|c|}{ "CARE" Model } \\
\hline $\mathbf{C}$ & Contextual modesty: A moderation that goes "beyond policing hemlines and cleavage." \\
\hline $\mathbf{A}$ & $\begin{array}{l}\text { Affordable, sustainable fashion: A commitment to "clothe our world affordably with } \\
\text { garments that will last." }\end{array}$ \\
\hline $\mathbf{R}$ & Responsible use of natural resources. \\
\hline $\mathbf{E}$ & $\begin{array}{l}\text { Ethical hiring, casting, and labour practices: "No one should profit from the abuse of human } \\
\text { beings for the purpose of sex or labour }\end{array}$ \\
\hline
\end{tabular}

Table 2: Christian Fashion Week “CARE” Model (Bauck, 2015)

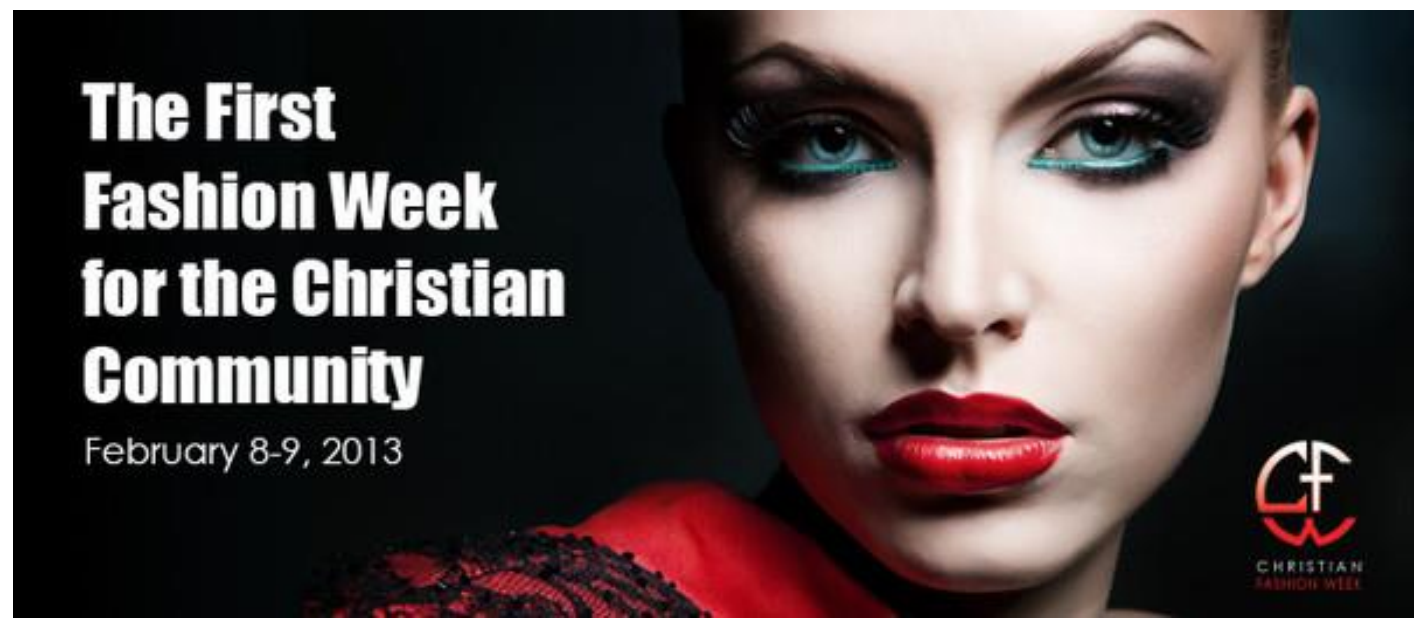

Figure 3: The first Christian Fashion Week. Source: examiner.com

\section{Summary}

This review adopted a thematic approach: focusing on Christian dress and identity in the context of Western cultures. Literature including books, articles, and websites/blogs have contributed to the scope of the research and have given insight into current trends on the issue of modesty. Nevertheless, the literature review indicates that there is need for further research and analysis on Christian dress and identity. However, in this research study, time was a constraint 
and did not allow for a more in-depth critical analysis of the literature to answer the research question in a more effective manner. Thus, further investigations into "faith and fashion," particularly on the runway, needs to be undertaken. With the revelation from the literature reviewed, one can undoubtedly say that it is not easy to be a Christian woman in this secular fashion world. Nonetheless, considering the size of this market niche, Christian women are not being catered for to some extent. Therefore, this qualitative study seeks to determine if dressing modestly and appropriately would require a special fashion system or platform. 


\section{Chapter 3}

\section{Research Methodology}

The qualitative approach of this study included in-depth interviews and direct observation in a church setting. The strategy exemplifies a cross-sectional design as the interviews were conducted over a 2-month period. However, this overt approach might have produced certain expectations; for example, participants might have projected a preconception on Christian dress and modesty. As a result, the degree of naturalism or ecological validity could be reduced (Gill \& Johnson, 2010). To counter this, a semi-formal relationship was developed through the direct contact with the participants (i.e., face-to-face encounters) in order to apply a covert approach to gathering the information. The objective was to have the participants share freely, their personal experiences and perspectives on the issues of modesty and appropriate dressing. Overall, "Christian dress and identity" was analyzed in general and in conjunction with a (brief) comparative review of other religions. Nevertheless, North America (a Westernized society), and more specifically the Greater Toronto Area (GTA), was the focus of this research.

\section{Research Sample}

While the context of this study was within the Western (North American) society, it was impossible and impractical to involve all Christian women in this research. As such, a sub-set of this market segment was selected by stratified sampling from which a random sample was drawn, as illustrated by Teddlie and Yu (2007), and the findings generalized for this target population of Christian women (Gill \& Johnson, 2010). Secondary data was used to draw relevant information and meaningful insights to answer the research questions effectively. For instance, key religious articles/documents/books/arguments were reviewed to enhance the analysis of the collected data. 
The GTA has a population of approximately 5.5 million (City of Toronto, 2016). Toronto alone accounts for 2.79 million and consists of $56.7 \%$ of Christians, 1,667,853 of whom are women (Statistics Canada, 2011). The research sample investigated a minute representation of Christian women in the GTA. However, as the research is concentrated in the City of Toronto, where the majority of the Christian population is located, a sample percentage would be a fair representation of Christian women in the GTA. The perspectives of 10 Christian women were investigated and evaluated in a qualitative manner. The study focused on what is considered modest and appropriate clothing for Christian (church) women.

This approach was suited as it allowed the exploration of faith and fashion from various lenses, as it relates to Christian dress and identity. The approach also provided a more flexible research plan. It was beneficial to undertake a qualitative research approach in order to uncover the authentic experiences and perspectives of Christian women in a Westernized society. The perspectives of others are important in analyzing fashion theory and concepts such as modesty and appropriateness. According to Kawamura (2011), "fashion/dress studies require various perspectives, approaches and interpretations" (p. 22). Although questions of reliability and validity have sometimes been raised as a concern in regards to qualitative research methods (Gill \& Johnson, 2010), careful and objective approach of the subject has been employed through a thorough and systematic procedure.

\section{Ethical Considerations}

As a requirement, the research design was reviewed and approved by the Ryerson University Research Ethics Board, as it involved human subjects (see Appendix A). Each participant recruited for interviews signed a Consent Agreement demonstrating that they were made aware of the nature of the study. The participants' information and their consent forms are 
kept strictly confidential and assured the subjects of anonymity. Ethical consideration was also given to the method of observation in a church setting. The church setting is considered public and as Flynn and Foster (2009) assert, "what a person wears in public is open for others to see, thus it may be documented" (p. 181). There are no risks associated with this research study; however, participants were given the option to withdraw from the study within a specific time frame.

\section{Interview Design and Questions}

The subjects were Christian women living in Toronto. This population is a representation of approximately $32 \%$ of the world's Christians. A sample of this population was chosen to conduct the study. The sample size was heterogeneous in denomination but homogeneous in their religion and society. A total of 10 adult Christian women living and attending church in the GTA were interviewed from five different denominations (Baptist, Catholic, Church of God, Pentecostal, and Seventh-Day-Adventist). The interviews were focused on their opinions and perspectives of modesty and appropriateness of dress and adornment in the church and formal settings. Due to different denominations and ethnic background of the participants, diverse perspectives and opinions toward dress and adornment were expected to emerge through the indepth interviews.

The general question posed for the study was: How do Christian women in a Westernized society go about choosing and obtaining "modest" and "appropriate" clothing for church and other formal occasions? The five specific categories that guided the interview were: (a) Fashion knowledge/consciousness, (b) the fashion industry, (c) Christian identity versus personal identity, (d) modest and appropriate attire, and (e) shopping behaviour/patterns for clothing (see Appendix B). 
The "Fashion Knowledge/Consciousness" category analyzed the general knowledge or consciousness of each participant held in terms of fashion consumption. It explored their sense of style or fashionability as it relates to the current industry and its rapidly changing cycles/trends. The "Fashion Industry" category gave insight into how each participant felt about the current fashion system/industry in terms of its influence on society (e.g. sexual attractiveness vs. modesty), and the degree to which the industry caters to Christian women. The "Christian Identity versus Personal Identity" category gave insight into how Christian women perceive themselves and their personal identity or perceptions of fashion, including what makes them feel fashionable, and what makes them feel like they are dressed appropriately, and the types/styles of clothing that reflect these attributes. The "Modest and Appropriate Attire" category guided the research in analyzing the various perspectives from the different denominations on the concept of modesty and appropriateness. Participants indicated their perceptions by selecting from a variety of styles/designs of clothing presented to them (see Figure 3) and rating the degree of modesty and appropriateness. Finally, the "Shopping Behaviour/Patterns for Clothing" category analyzed shopping behaviours/patterns of Christian women and how their shopping is being influenced. In other words, do they feel pressure from the industry to be in (current) style, how often they shopped, and what helps them decide to make a purchase - Do they have difficulty in finding something to fit their level of modesty and appropriateness?

\section{Recruitment and Interview Setting}

The selection criteria of participants were based on age (18 years or older), gender and religion (female Christian). These participants were recruited by way of a recruitment poster (see Appendix C) as well as personal approach at specific church locations. The response to the recruitment to be interviewed was voluntary and observation was conducted discreetly, while 
attending church services. A scheduled interview time of 30 to 45 minutes was arranged with each participant in advance, and participants were interviewed in a private room at a public library location convenient to the participant. A semi-formal relationship was established where participants felt free to express their opinions and share their perspectives on the research topic. Data was collected through clear audio recording and the duration of each interview did not exceed 45 minutes.

\section{Setting of Observation}

Observation was also undertaken in a public space: a church setting. The churches were located in the GTA and various church services were held on Saturdays and Sundays, depending on the denomination. It was appropriate to observe participants in this setting, as Christian women would be dressed in certain attire that they considered modest and appropriate for church service. In a church setting, observation would be appropriate as participants would be unsuspecting and so they would dress in what they perceive to be modest, appropriate, and comfortable for the occasion. As Flynn and Foster (2009) purport, observation is used for various purposes in the fashion industry (e.g., to observe shopping behaviour or attitudes in dress) and the observer can disguise the research. Thus, attending and participating in the worship services allowed for such purpose.

\section{Analytical Method}

Through the analysis of open-ended interview questions, the research discussed and presented the difficulties in finding modest and appropriate fashion for professed Christian women in a secular fashion industry. The key variables in the research study included "modesty" and "appropriateness"; that is, what constitutes modesty and what constitutes appropriate dress. The main method of data analysis was the inductive development of theory through the use of 
analytic induction. According to Gill and Johnson (2010), analytic induction aids in the causal analysis of qualitative data in order to explain variation in phenomena. As such, interpretative theories were built from the data collected and elaborated on. The process of analysis included the identification of particular views on "Christian dress and identity" from Christian women. An audit trail was developed to track the process of data collection and analysis. This "record" covered all aspects of the research as noted by Gill and Johnson (2010). The benefits of such a record, as purported by the authors, helped in answering some important questions relevant to the evaluations of the findings. Coding procedures and interpretative method were developed in the specific interview/question categories. The concepts of modesty and appropriateness were the key variables for analysis. The Interview Guide (see Appendix B) formed the basis for this qualitative analysis. As mentioned earlier, the questions were grouped in five categories. All questions were open-ended type to allow the participants to use their own words to express their opinions and experiences. The participants were given time to elaborate on their responses to certain questions for clarity and correctness. 


\section{Chapter 4}

\section{Research Findings/Analysis}

The purpose of this research was to gain an understanding of the experiences of Christian women in finding modest and appropriate clothing for church or other formal occasions. Therefore the key variables in the research study are modesty and appropriateness as they relate to Christian dress and identity. The understanding of their experiences in acquiring clothing and the awareness of how fashion may impact an individual self (Christian and personal identity) will enhance fashion practitioners' and marketers' ability provide modest and appropriate apparel for Christian women. This is particularly valuable, since they are niche market segment that makes up a great proportion of the apparel market. Importantly, this study also highlights the relationship between the meaning of modest/appropriate dress and Christian identity.

\section{Importance of Fashion}

Fashion is a very important aspect of our everyday lives regardless of our ethnicity, status, or religious affiliation. When asked, "What role does fashion play in your life?" one participant (P2) responded, "I would like to say that it doesn't [play a role in my life] but in reality it does." Another respondent (P4) said, "It encompasses my daily routine." Nine participants acknowledged that fashion played a very important role in their lives because clothing "protects us," "identifies us," and "at times labels us” (Breward, 1995; Flugel, 1930). People are often judged by their outward appearances (Bacchiocchi, 1995) regardless of what is in the heart and mind. Flynn and Foster (2009) argue that individuals use symbols such as clothing or dress to develop, acquire, and communicate identities, and that meanings of appearance are constructed in part through social interaction and contribute to the meanings they 
assign to their appearances (p. 39). Thus, a Christian woman's desire is to display outwardly (in her manner of dress) what is in her heart and mind, as true witnesses of her faith.

\section{In-Depth Interviews}

Data was collected through in-depth interviews with10 Christian women, as well as observation in a church (service) setting. The participants were aged from 20 to 68 years with the mean age 43.3 years. The ethnicity was mixed with $50 \%$ of the participants being black. The distribution of church denomination among participants was even, as shown in Table 2. Specific categories of questioning were used to guide the interviews, which formed the five themes discussed below in the analysis of the results.

\begin{tabular}{|c|c|c|c|c|c|}
\hline Participant & Age & Occupation & Race/Ethnicity & Marital Status & Denomination \\
\hline P1 & 55 & Nurse & Black & Married & Seventh-Day \\
& & & & Adventist \\
\hline P2 & 25 & Student & Black & Single & Church of God \\
\hline P3 & 30 & Office Clerk & Black & Single & Pentecostal \\
\hline P4 & 35 & Office Clerk & White & Married & Catholic \\
\hline P5 & 45 & Supervisor & Black & Single & Baptist \\
\hline P6 & 20 & Fashion & Filipino & Single & Seventh-Day \\
& & Stylist & & Adventist \\
\hline P7 & 40 & Secretary & White & Married & Catholic \\
\hline P8 & 50 & Teacher & Filipino & Married & Baptist \\
\hline P10 & 65 & Retired & Black & Single & Pentecostal \\
\hline
\end{tabular}

Table 3: Participant's Profile 
Fashion knowledge/consciousness. A general knowledge or consciousness in regards to fashion was assessed. The participants' sense of style or fashionability was an important aspect in determining what role fashion played in their lives as Christian women, which would contribute to their views on Christian dress and identity. When asked, "What comes to mind when you think of fashion?" the participants' responses included: glamour; beauty; clothing; accessories; and trends. Some participants expressed that they liked to look fashionable but not as indulging in fashion. Many participants were aware of current fashion trends and cycles. Participant P1 described that "fashion comes in and goes out." Although many participants were sensitive to fashion trends, the majority of the participants preferred wearing timeless or longlasting clothing.

Sixty per cent of the participants indicated that they did not use magazines, celebrities, or fashion runways for fashion information and inspiration. In other words, these fashion information sources did not influence their clothing choices. They wanted to use clothing and personal style to express who they are rather than following the fashion trends. However, it is important to note that some participants tended to use different sources to seek colour information of the upcoming season. Based on their responses, it is reasonable to suggest that many Christian women felt confident and they trusted their personal taste or sense of style in fashion. They were not concerned about what family or friends thought about their style. For example, one participant (P1) stated, "What influence me is from within." Essentially, it is her personal and Christian values that come into play when she thinks of fashion. Nevertheless, Christian women are more engaged in the secular fashion world than they would want to admit (P2). 
Shopping behaviour/patterns for clothing. By assessing the shopping behaviours of the participants and their patterns for obtaining apparel products, this section of interview determined the extent to which fashion may play a role in the life of a Christian woman, as they are expected to be less influenced by the secular world such as today's fashion system and consumer culture (O’Cass \& Julian, 2001). This category of interview was used (1) to explore whether the participants feel any pressure to conform to the current fashion trends; (2) to reveal how often they shop and what helps them make a purchasing decision; and (3) to determine the degree of difficulty in finding modest and appropriate clothing for church and other formal occasions. However, although the participants indicated that fashion did not play a major role in their lives and their clothing purchases were primarily classic styles that can be worn for many years, on average they spent approximately $\$ 2,000$ per year on fashion items.

Some participants revealed that they shopped for apparel according to the changing seasons, while others indicated that they shopped when a need arose (e.g., for special occasions and events). When asked if they see themselves as a trend-setter or a follower, $80 \%$ stated that they purchase and wear whatever they like, not because someone is wearing it. The decisions were strictly personal and were based on modesty and what was appropriate for church. Collectively, there were concerns about the length of a dress or skirt when shopping for an outfit. As such, when making a purchasing decision, their concerns often related to a number of areas the length, cleavage, arms, and proper fit/size. However, the perception of modesty varied among participants when deciding what to purchase. In other words, modesty was a subjective concept among the participants due to the age and cultural variance. Therefore, modesty and appropriateness of clothing was often based on the consumers' taste and personal judgment because there is no specific and standard guideline for the Christians to follow. As a result, what 
one Christian woman may deem as modest might not be considered as such by another Christian woman. Nevertheless, the shopping behaviours or patterns for acquiring clothing were similar among the participants. Basically, they would browse particular stores and look for what suited them in terms of price, quality, and personal style. They shopped for clothing mainly when their needs occurred or a particular item was on sale.

Christian identity versus personal identity. The research required an understanding of how Christian women perceived themselves in relation to fashion. What makes them feel fashionable? What makes them feel like they are dressed modestly or appropriately? The participants were also asked to describe the type/style of clothing that reflects their identity. When asked if their fashion style relates to their Christian identity, or their personal identity, or to both identities, $90 \%$ indicated that both their Christian and personal identities were related and that it is difficult to separate the two. Some of them also mentioned that their identity (personal/Christ-like) was developed and certain beliefs and values were deeply ingrained in them from childhood. This line of questioning sought to find the relationships between personal identity and Christian identity in order to find out how a Christian identity may be influenced by the perceptions of others. According to the responses to a question: "What do you think society expects of you when it comes to fashion?" many participants perceived that society often expects them to dress modestly. Participants were aware of how others (society) perceived them as a Christian and the majority of the participants felt that they had a responsibility to dress in a certain (modest) manner. However, some participants (e.g., P6) expressed that society tends to see Christians as boring and bland, when it should be quite the opposite. The argument is that Christian women should "shine" so the world can see them (both modestly and fashionably dressed). Thus, the Christian woman should present herself beautifully because she believes (in 
scripture) that she is fearfully and wonderfully made. As Psalm 139:13-14 described, "For you created my inmost being; you knit me together in my mother's womb. I praise you because I am fearfully and wonderfully made; your works are wonderful, I know that full well.” Accordingly, as one participant (P5) noted, a Christian woman should look elegant and stylish, so others or unbelievers would want to know more about her and her beliefs.

Most of the participants perceived themselves to be modest in their dressing because they do not wear short, revealing clothing or show too much skin. This self-consciousness is also confirmed when others compliment their modest appearance and ask them about the place they shopped. When asked how they felt when such comments are made, some participants responded that it boosted their confidence in their (modest) appearance. However, some expressed that it did not matter if someone commented or not, because they were comfortable within themselves; emphasizing that dressing modestly is just who they are-a personal attribute or their personal identity. As such, their personal identity is reflected in the way they coordinate their clothing and accessories. For one participant, elegance and sophistication played an important part in her style. She always coordinated her shoes with handbag or purse, for example, if she was wearing a hat, we would like to portray a sophisticated and fully coordinated look or image. Does your style relate to your Christian identity? "It certainly does," said one participant (P1) whose style and personal identity was intertwined in her Christian identity from a very young age.

Undeniably however, the secular world has indirectly influenced Christian women in their dress and identity ("Religion and Dress", 2009). Many Christian women also fall victims to the current fashion and trends (Matthews David, 2015) and this is what the Apostle Paul in 1Timothy 2:9-10 was admonishing the Christian church in Corinth about, as certain attitudes and practices were being practiced among church members. Today, many church leaders are still 
cautioning about similar issues (Wood, 2011). Short skirt/dress length and exposed cleavage/skin is considered inappropriate for a Christian woman. All the participants described this manner of dressing as inappropriate for church setting/service or for a Christian woman in general.

Appropriate and modest attire. This category analyzed the various perspectives of Christian women and provided insight into what is considered modest and appropriate. As such, participants were asked to define modest and appropriate clothing. The findings clearly indicated that the participants held similar views and perceptions of the concepts. In regards to modesty, many participants reported that there should be nothing too tight, exposed, or revealing which included the neck, arms, bust/cleavage, and legs. For one participant (P1), she views full length skirts/dresses to be modest and felt that clothing should not reveal and emphasize too much of the body. Another participants stated that "everything should be in balance" (P7), and "not bringing lust onto other people" (P6). They argued that there should be appropriateness in how you dress when attending church, and the manner of dress should not be "party fashion" or "casual." We dress differently for a job interview or to present in front of a judge. Therefore one should show respect in a church gathering as you are in the presence of God. A Christian woman or any woman for that matter should take into consideration what kind of message that they want to send in their manner of dress, as our dress communicates who we are (P8).

When asked, "Do you always dress modestly?" most participants replied "yes." These participants argued that it is just a part of who they are. For others, it depended on other factors. One participant explained that she dressed differently when dressing for work or other occasions. For church, she would make sure that her clothing had sleeves that are at the "appropriate" length. However, for a social occasion, she may wear something without sleeves and if the design of her outfit does not cover her shoulders completely, she may wear a bolero top to cover 
her arms. For work, she would wear pants but she would not wear pants to church. Although the pants cover her leg, she would not wear it to church. When asked about why, she stated that "I would not wear a pant to church because ... for me, wearing a pant to church is not modest" (P1). She further stated that, "in my religion, we don't wear pants to church" (P1). Here, it is evident that modesty is indeed a relative and subjective concept.

In acquiring clothing for church or other formal occasions, most of the participants seemed to have difficulties or challenges in finding a skirt/dress in appropriate length. Many of them shopped in specific stores that cater to their clothing needs to a certain extent, depending on the occasion. Some used custom-made or tailoring services to meet their needs. The stores in which they shopped to find modest and appropriate clothing were rated less than 7 on a 10-point scale. This suggests that the offerings of modest apparel is limited in today's retail market.

Perceptions of modesty, appropriateness, and personal style. Participants not only were asked to describe their own perceptions of modesty and appropriateness in relation to Christian dress, but also to view various designs in clothing to determine the degree of modesty perceived by Christian women and how they determine what is appropriate for an occasion such as church. 


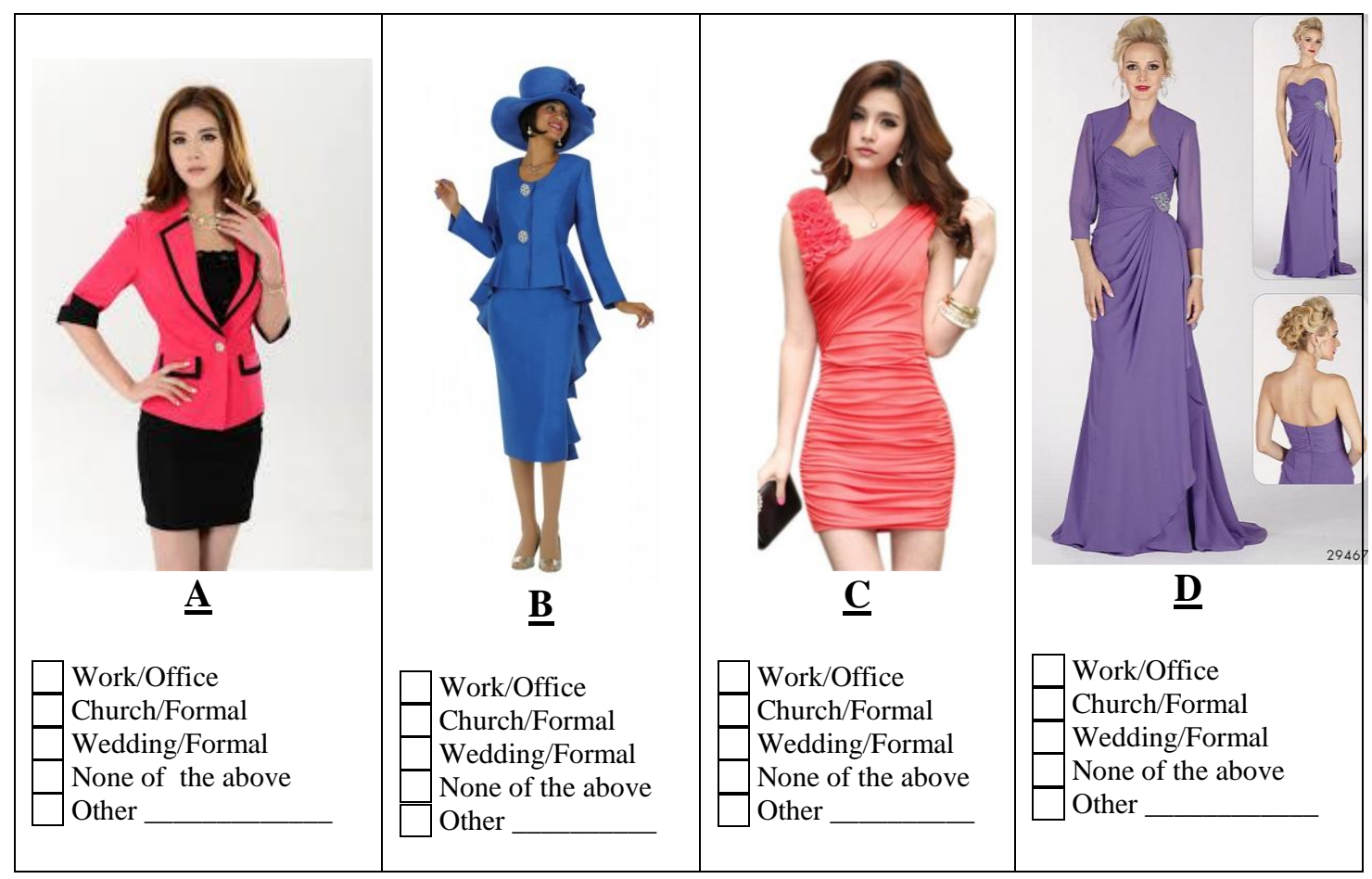

Figure 4. Perceptions of modesty and appropriateness. Source: Google Images (2015)

Five images were presented to the participants, and then they were asked to indicate which of the outfits (shown in Figure 3) depict the concept of modesty, and why. Basically, all the participants indicated that item B fits their personal perspective of modesty and is appropriate for church. One participant included item D. The reason was that item B provides full coverage of the sensitive areas, such as the neckline, the length, arms, fit, and fashionability. While item D was not considered appropriate for church - it is formal and modest because there is a bolero top to cover the shoulders and the dress length is respectful. Many indicated that they would wear item $\mathrm{B}$ to church and item $\mathrm{D}$ to a wedding. Item $\mathrm{A}$, on the other hand, missed the mark of modesty due to the length of the skirt. Many commented that the skirt could be longer and it would be more appropriate to wear at work. Some stated that they would wear it to church; however, they would adjust the length. Item $\mathrm{C}$ was labelled a party dress, not suitable for church, work, and a wedding. It is too casual and not respectful. The conclusion was that each outfit was 
suited for a specific occasion. Seventy percent of respondents stated that item B was the closest to their personal style as a Christian woman.

Observation. Observations of Christian women were also conducted within a church (service) setting. The key aim of this research method was to observe the manner of dress and adornment of women attending church services. This method was considered appropriate for the study as it allows the researcher to become engaged in the attitudes and behaviours of the subject group, "looking at the people and what they wear" (Flynn \& Foster, 2009, p. 175). The church services were attended and the observation was conducted and documented in a discreet manner. Three churches were selected randomly in the GTA for this observation, including a small-size (Church of God), a mid-size (Pentecostal), and a large-size (Seventh-day Adventist) church. The size of the congregations ranged from approximately 300 to 600 persons. The size of the congregation was determined approximately by the number of pews.

Church no. 1. The Church of God congregation was the smallest one as compared to church \#2 and \#3. It seemed the number of female members was higher than males and the membership consisted mainly of mature adults and seniors. Very few youth or young adults were attended in the service. According to my observations of how they dressed, these mature women were very modest in appearance. The lengths were appropriate and they were all covered up in long sleeves. The age group of these women ranged from 45 to over 65 years. I assumed that the age may play an important part of how they dressed. They appeared very solemn in their attitude perhaps this may relate to the nature of the service. Many women were also wearing hats that seemed to be coordinated with their outfits as a form of style. I also assumed that the weather outside may have been a factor in their manner of dress (i.e., the reason for being covered up). 
Church no. 2. I considered this church (Pentecostal) to be a mid-size congregation. The attendance was mixed with youth and seniors. The atmosphere and service within this church was more joyous and vibrant. There were drums being played and other musical instruments. The youth were leading out in the praise singing. The manner of dress observed among the young women generally was modest. However, the lengths varied according to the style/design of the garment. There were no signs of unnecessary skin showing as most women were wearing stockings, long skirts, and long sleeves. There were plenty of fashion hats being worn as head coverings that coordinated with the outfits. The outfits I observed, primarily those being worn with hats, were very fashionable and sophisticated. I complimented one woman on her outfit and hat. I also asked her where she shopped, and she told me that she usually shops in the United States. Based on my observations, it is reasonable to suggest that this was a fashionable group of church women and that they took pride in dressing and looking their best for church. It seems to me that this group had no difficulty finding modest and appropriate clothing for church.

Church no. 3. On the other hand, the church with the largest attendance (Seventh Day Adventist) seemed to have issues of modesty. This congregation consisted of a wide variety of apparel styles. Although this observation was also conducted in the fall/winter season, most of the members were wearing short hemlines (some with stockings and some without), unlike the two previous congregations whose members were mostly wearing long skirt lengths. I had difficulty determining this group of Christian women. This was really a very fashion-conscious congregation. I saw all the variations of trendy styles, worn for fashion statements as opposed to reflecting a Christian identity. The individual self was being emphasized and portrayed more than modesty. I did not sense solemnness in the service. Although I was there to observe what Christian women were wearing, I was distracted by the manner of dress (the way they dressed 
and behave) that some of them portrayed and presented in a church setting. I began questioning or judging whether the person was a Christian woman. The youth and young adults whom I observed did not demonstrate any attitude of reverence or Christ-like behaviour. They were loud, constantly talking, chewing gum, and attending to their electronic devices. However, I had to remain as objective as possible. I could not make a judgment that all women who attended church services are Christian women. I concluded that this church was a very fashion-forward, affluent congregation and it may have been an example of a church where the issues of modesty and appropriateness were constantly debated. It seemed that most of the women within this church conform to the current fashion system.

\section{The Fashion Industry}

Determining how Christian women felt about the current fashion system/industry in terms of its influence on society and regard for modesty was also an important factor in this research. If Christian women are aware of the modesty issues affecting their dress and identity within the industry, how then do they go about mitigating these issues? Are they just conforming because they think there are no alternatives? Or do they think that Christian women can create their own fashion system? When asked about their rating (on a scale of 1-10) of the fashion industry in catering to their needs as Christian women, the responses varied tremendously. One participant rated the only store she said she could find something modest as an 8. According to the participants, the degree to which Christian women are being catered to in the consumer market for fashion was rated on average as 4 . One participant stated that:

I don't think the industry is catering for Christian dress. They are created for a casual wear. Yes I've seen ... modest dress length-wise on the runway, but when you look above the waist, it's not modest. The cleavage is out, the arm is out, but 
the skirt is long. Yes the skirt is modest, but the top is not modest, or the top is modest and the skirt is not modest. So you have to look for a balance between both top and the bottom. (P1)

When I asked the same participant if she could influence the fashion industry or a major designer or retailer of ladies fashion, she stated that she would encourage them to design more modest fashion and let them know what Christian women (who represent a large portion of the market) are looking for. She expressed that:

Christians are looking for modest dress, the length of dress and the arms covered. The back not too low, the cleavage is, you know, your breast is not out. It's not too tight that men are lusting in church or places like that. And we have a lot of Christian people around that are looking for clothing and can't find it, and cannot find anybody to make it either. ... So we have to ... really put on our "spectacles" or look for someone to make the clothing that we need because it's not out there. (P1)

On the other hand, some participants actually identified with the industry arguing that it is how you wear the fashion (P2). Some of them such as P7 argued that the fashion industry is no longer religion-based - that fashion is all about individual expression. For others (P5 and P6), Christian women are not considered a business client because the clothing being mass marketed appeals to sexuality (more skin, cleavage, and legs), as sexiness promotes sales. Interestingly, one participant (P8) identified a designer who incorporates some elements of modesty that is also trendy and fashionable that Christian women could wear. Some participants also indicated that they could shop for modest clothing at a number of stores including Melanie Lynne, Reitmans, The Bay, and Sears. However, there was not much on offer in terms of style or fashionability. As such, most of them shop in the U.S. or online to find modest, elegant and fashionable clothing. 
Thus, this is one of the reasons why the online market for modest apparel has been growing over the years (Lewis, 2011). 


\section{Chapter 5}

\section{Discussion and Conclusions}

With the literature reviewed and the findings from the qualitative interviews and observation, one can undoubtedly say that it is not easy for Christian women to dress modestly in a secular fashion world. The findings suggest that there are religious expectations in Christian dress and adornment. It also means that one cannot pretend to be a Christian. As the Bible states, "man looks on the outward appearance, but God looks on the heart" (1Samuel 16:7). Therefore, your (outward) dress could be displaying what is evidently in your heart. Besides, society has implicit notions and certain expectations when it comes to professed Christian women and how they should dress as expressed by the participants and the religious realm. Thus, Christian women to a great extent are not being served by the fashion industry, considering the size of this market.

This research demonstrated that Christian women, regardless of their affiliation, take into consideration the degree of modesty and appropriateness that would depict their identity when shopping for clothing and fashion items. Our bodies and what we wear helps to form our identities. Christian women are fashion conscious and so their shopping behaviours are influenced by this consciousness. They are also human and are prone to the fashion influences around them. However, according to the Bible, they are reminded that they are in the "world" but not of the "world" (John 17:16), meaning that Christian women should be free of "worldly" influences such as "worldly"/immodest fashion. As such, their dress and demeanour should identify them as Christians.

Most of the participants, however, did not seem to be heavily influenced by the fashion system, in that they do not follow the trends. However, most of them will shop according to the 
season (spring/summer) and they would purchase classic or staple items/fashion. On the other hand, some participants stated that they wear and purchase what's in style. They have a good sense of fashion and are not naïve to the current trends and issues within the fashion system. For Christian women, their manner of dress and identity are related. For them, these aspects share the same values that are ingrained in their personality. Most participants described their clothing styles as classy, sophisticated, and fashionable; this means they are very much in-style. The problem many faced was finding clothing that suits the image of modest elegance, particularly for church and other formal occasions.

A majority of the participants described their fashion style as closely linked to their personal identity. Therefore, if their fashion style is linked to their personality and their fashion style reflects their Christian identity, then these two identities can be considered as a unified one, identical, or related. In other words, their Christian identity "outwardly displayed" must reflect their personality from within. Then their personality is what's coming from the heart.

\section{Summary of the Study}

The findings throughout this research suggest that the concept of modesty is relative and subjective. It is subject to the individual's interpretation and style. Unlike other religious groups (Mormons, Muslims, and others), there are no findings in any of the literature reviewed, including the Bible, regarding what the length of a skirt or dress should be to classify an outfit as modest. There is no specification of what modesty is in the context of religion, only that women should dress with decency and propriety (1 Timothy 2:9). It is the judgment of the individual. What is viewed as being modest in the eyes of one is not necessarily modest for another. In making this determination of "modesty" or "appropriateness," it is important to ask the question when you get dressed: Who within your heart are you dressing for? 
In answering my research question, these findings have shown that Christians are implicitly and explicitly expected to dress appropriately and modestly, but the fashion industry does not consider this market segment. As such, it is difficult to find modest and appropriate clothing for church. As a result, many Christian women have to look for other alternatives such as tailoring and custom-made designs. The findings, however, support the view that Christian fashion designers need to establish their own fashion system, have their own runway shows, and market to this target segment for modest apparel.

\section{Limitations of Study}

The research study was limited in scope as a result of time and resources. The data would be more reliable if the sample size was larger. The research was also conducted within the fall/winter months, which could affect the true outcome of the research study given that women usually dress more modestly in the cooler temperatures. Conducting this research during the summer months as well would give a clearer picture of the dress practices of these (Christian) women. Would they be all covered up in summer?

Nevertheless, this research study can offer new insights and information to the existing body of knowledge, particularly on the topic of "faith and fashion." This research may also influence the current fashion system - not only to acknowledge the unsatisfied needs of Christian consumers but also to take another design approach (e.g., co-design) to fulfill the needs of this particular demographic group which comprises approximately $67.3 \%$ of Canada's population (Statistics Canada, 2014), not to mention the rest of the Western world. 


\section{Appendix A: Ryerson Ethics Board Approval}

Ryerson

University
RESEARCH ETHICS BOARD

To: Jacquline Smith

Fashion

Re: REB 2015-308: Faith and Fashion: Christian Dress and Identity

Date: October 22, 2015

Dear Jacquline Smith,

The review of your protocol REB File REB 2015-308 is now complete. The project has been approved for a one year period. Please note that before proceeding with your project, compliance with other required University approvals/certifications, institutional requirements, or governmental authorizations may be required.

This approval may be extended after one year upon request. Please be advised that if the project is not renewed, approval will expire and no more research involving humans may take place. If this is a funded project, access to research funds may also be affected.

Please note that REB approval policies require that you adhere strictly to the protocol as last reviewed by the REB and that any modifications must be approved by the Board before they can be implemented. Adverse or unexpected events must be reported to the REB as soon as possible with an indication from the Principal Investigator as to how, in the view of the Principal Investigator, these events affect the continuation of the protocol.

Finally, if research subjects are in the care of a health facility, at a school, or other institution or community organization, it is the responsibility of the Principal Investigator to ensure that the ethical guidelines and approvals of those facilities or institutions are obtained and filed with the REB prior to the initiation of any research.

Please quote your REB file number (REB 2015-308) on future correspondence.

Congratulations and best of luck in conducting your research.

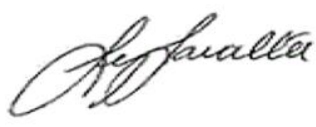

Lynn Lavallée, Ph.D.

Chair, Research Ethics Board 


\section{Appendix B: Interview Questions}

\section{The general research question}

"How do Christian women (in Ontario, Canada) acquire 'modest' and 'appropriate' clothing for church and other formal occasions"?

\section{Specific Questions}

\section{Fashion Knowledge/Consciousness}

* When you think of fashion what comes to mind?

* What role does fashion play in your life?

* What types of media/medium do you consult for fashion inspiration or ideas? For example: friend, window display, people in the street, TV, magazine, fashion website, fashion blog, etc.

* Why do you look to these media/mediums?

\section{Shopping Behaviour/Patterns for Clothing}

* How often do you shop for clothing/fashion items?

1. Do you wear/shop according to the seasons?

2. Are you a trendsetter or follower?

* On average, how much do you spend on clothing per month/Year?

* What is/are your favourite brands and/or stores?

* How do you go about deciding - when purchasing a clothing item?

1. Do you try to purchase/wear what's in style?

\section{Christian Identity vs Personal Identity}

* How long have you been attending church?

* How do you view yourself when it comes to fashion and dressing?

1. How do you think others perceive you?

How do you go about coordinating your clothing or fashion style?

1. Does it matter what you wear? Why or why not?

How much time do you spend selecting/deciding what to wear?

* Describe your fashion style when it comes to fashion and your personal identity

* Does your fashion style relate to your Christian identity, your personal identity? Or both?

* Have you ever received negative/positive comments from people (or friends) because of the way you dress, what you're wearing, or your interest in fashion? If so, how did you react? Share an example.

* As a Christian woman, what do you think society expects of you when it comes to fashion? How do you relate to that?

\section{Appropriate and Modest Dressing/Clothing}

* How would you define 'modest' and 'appropriate' clothing?

* What are your views on appropriateness and modesty in dress - as it relates to Christian dress and identity?

* Describe what you would view as appropriate and modest fashion/clothing - generally and specifically for a Christian woman. Why? 
* How do you think others (Christians or non-Christians) view you in your dress/fashion? Do you think you are being scrutinized/criticized? If so why?

* Describe how you dress for church or any other formal occasion?

1. What are some of the considerations/decisions you make in dressing?

* Do you always dress modestly - or is it just when you are attending church? Why is that?

* What are your challenges and concerns when shopping for clothing?

* How do you normally acquire appropriate and modest clothing for church and/or special occasions?

\section{The fashion industry}

* What do you think of the fashion/apparel industry (in relation to Christian dress) when it comes to fashion runway shows, magazine ads/commercials - in catering to your needs as a Christian woman?

* Are there any fashion stores (including online) that cater to your needs as a Christian woman? If so what are the names of these stores?

* On a scale of 1-10, how would you rate each of these stores for catering to your needs?

* Which store do you shop more often to purchase clothing for church - and why?

* On a scale of 1-10, to what degree do you think Christian women are being catered to in the consumer market?

* If you were in a position to influence a major fashion designer or retailer, what would be your fashion needs and concerns as a professed Christian woman - that you would like to be considered for future clothing designs/collections for Christian women?

\section{Perceptions of Modesty and Appropriateness (see Appendix B)}

* Explain the appropriate occasion for which you would wear the following outfits

Which of these outfits depicts your perspective of modesty and why?

* Which of these outfits is appropriate for you?

* How do you normally obtain clothing for church and/or formal occasions?

* Have you ever had your clothing custom-made? Why or Why not?

\section{Demographics}

What is your age range?
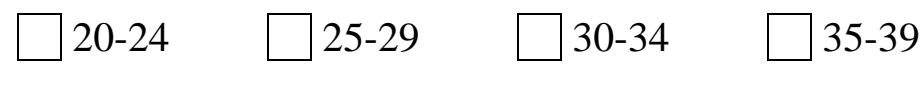

$\square 40-44$

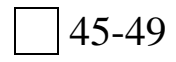

$\square 50-54$
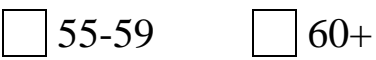

Gender

Marital Status

Education

Occupation

Household Income 
Appendix C: Recruitment Poster

\section{Faith \& Fashion}

Interested in research?
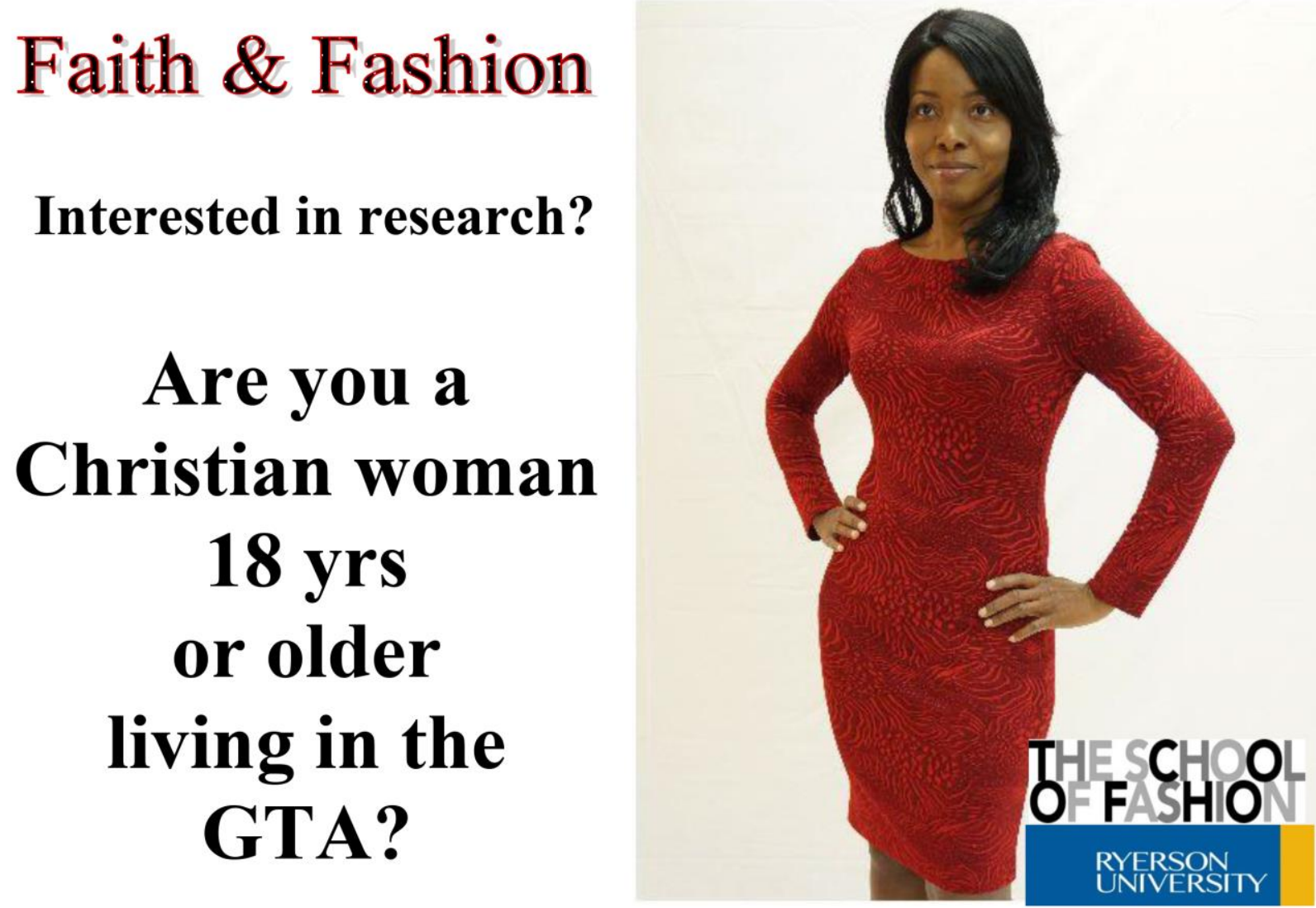

Seeking 10 Christian women to participate in a research study on 'Faith and Fashion'

Share your perspectives by answering questions in a 45-60mins one-on-one interview at Ryerson University on 'Christian dress and identity'

Please contact Jacquline Smith at: jacquline.smith@ryerson.ca

** This research complies with the Ryerson Research Ethics Board guidelines for recruitment and research procedures ** 


\section{References}

Alcorn, R. (2016). The need for the Christian families to address the issues of modestly. For the Family. Retrieved from http://forthefamily.org/need-christian-families-address-issuemodesty/

Alsop, V. (2010). Avoiding immodest fashions. Modest Apparel, 216, 11-15. Retrieved from http://www.chapellibrary.org/files/8113/7658/4056/mappfg.pdf

Afshar, H. (2006). Can I see your hair? Choice, agency and attitudes: the dilemma of faith and feminism for Muslim women who cover, Ethnic and Racial Studies, 31(2), 411-427.

Arthur, L. (2016). Religion and dress. Fashion history-eras. Retrieved from: http://fashionhistory.lovetoknow.com/fashion-history-eras/religion-dress

Ash, J. (1999), The aesthetics of absence: Clothes without people in painting, in Amy De La Haye and Elizabeth Wilson (eds.), Defining Dress: Dress as Object, Meaning, and Identity. New York: Manchester University Press.

Ashworth, P. (2012). Psychology and "human nature” [Kindle version]. Retrieved from http://site.ebrary.com.ezproxy.lib.ryerson.ca/lib/oculryerson/reader.action?docID=10053 856

Bacchiocchi, S. (1995). Christian dress and adornment: Essays by Laurel Damsteegt and Hedwig Jemison. Berrien Springs, MI: Biblical Perspectives. Retrieved from http://www.anym.org/pdf/christian_dress_and_adornment_samuele_bacchiocchi.pdf

Bacchiocci, S. (2008). Christian dress and adornment [Video file]. Retrieved from https://www.youtube.com/watch?v=FSACykUJFBs

Bacher, W. \& Dembitz, L.N. (2011) Sumptuary laws. Jewish Encyclopaedia. Retrieved from: http://www.jewishencyclopedia.com/articles/14111-sumptuary-laws 
Bailey, S. (2013). Clerical vestments: Ceremonial dress of the church. Oxford: Shire Books.

Bauck, W. (2015). Fashion matters. Christianity Today, July/August, 74-80.

Baxter, R. (2010). Your clothing reveals your heart. Modest Apparel, 216, 17-19. Retrieved from http://www.chapellibrary.org/files/8113/7658/4056/mappfg.pdf

Bayas, L. S. (2009, February 4). The church vs. haute couture. Trend Hunter. Retrieved from http://www.trendhunter.com/slideshow/the-controversial-blending-of-fashion-withreligion-the-church-vs-haute-cou

Becker, H.S. (1991). Outsiders: Studies in the Sociology of Deviance. New York, NY: The Free Press.

Bellatory (2015) Women's fashions of the Victorian Era: From hoop skirts to bustles 1837 - 1901. Retrieved from: https://bellatory.com/fashion-industry/Fashion-HistoryVictorian-Costume-and-Design-Trends-1837-1900-With-Pictures

Blair, L. (2014, January 28). Christian women who wear clothes outlining shape of their body are "sensual" and "wrong," says Preacher Paul Washer. Christian Post. Retrieved from http://www.christianpost.com/news/christian-women-who-wear-clothes-outlining-shapeof-their-body-are-sensual-and-wrong-says-preacher-paul-washer-113519/

Blakesley, K. C. (2009). A style of our own: Modesty and Mormon women, 1951-2008.

Dialogue: A Journal of Mormon Thought, 42(2), 20-53. Retrieved from https://bycommonconsent.files.wordpress.com/2010/03/blakesley.pdf

Blumer, H. (1986). Symbolic Interactionism: Perspective and Method. Berkeley and Los Angeles, CA: University of California Press.

Breward, C. (1995). The culture of fashion: A new history of fashionable dress. Manchester, UK: Manchester University Press. 
Brundage, J.A. (1987). Sumptuary laws and prostitution in late medieval Italy. Journal of Medieval History, 13(4): 343-355.

Bunyan, J. (2010). Symptoms of bodily pride. Modest Apparel, 216, 9-11. Retrieved from http://www.chapellibrary.org/files/8113/7658/4056/mappfg.pdf

Carlin, A. (2013, November 29). Religion calls out fashion. Hunger. Retrieved from http://www.hungertv.com/feature/religion-calls-fashion/

Chen, M. (2012). A dressing down on dressing down. The Sword and Trowel, 1. Retrieved from http://www.metropolitantabernacle.org/Christian-Article/Principles-in-ChristianDressing/Sword-and-Trowel-Magazine

City of Toronto. (2016). Diversity. Retrieved from http://www1.toronto.ca/wps/portal/contentonly?vgnextoid=dbe867b42d853410VgnVCM 10000071d60f89RCRD\&vgnextchannel=57a12cc817453410VgnVCM10000071d60f89 RCRD

Craddock, J. (2012, May 4). Express yourself through style [Web log post]. Retrieved from https://peppermintstyle.wordpress.com/2012/05/04/express-yourself-through-style/

Craik, J. (1994). The face of fashion: Cultural studies in fashion. London, UK: Routledge

Dallas, K. (2014, October 27). How faith is making modest fashion trendy. Desert News. Retrieved from http://national.deseretnews.com/article/2626/how-faith-is-makingmodest-fashion-trendy.html

Du, H., \& Jonas, E. (2015). Being modest makes you feel bad: Effects of the modesty norm and mortality salience on self-esteem in a collectivistic culture. Scandinavian Journal of Psychology, 56(1), 86-98. doi:10.1111/sjop.12175

Entwistle, J. and Wilson, E. (2001). Body Dressing. New York: Berg. 
Evans, M. (1989). Consumer behaviour towards fashion, European Journal of Marketing, 23(7): 7-16.

Flugel, J. (1930). The psychology of clothes. London: Hogarth Press and the Institute of Psycho-Analysis, 1930. Retrieved from: http://catalogue.library.ryerson.ca/record=b1029828

Flynn, J. Z., \& Foster, I. M. (2009). Research methods for the fashion industry. New York, NY: Fairchild Books.

Freitas, A., Davis, C.H. and Kim, J.-W. (1997). Appearance management as border construction: least favorite clothing, group distancing, and identity ... not! Sociological Inquiry, 67(3): 323-335.

Gilkerson, L. (2013, August 16). 6 marks of Biblical modesty: How God brings sexy back [Web log post]. Retrieved from http://www.covenanteyes.com/2013/08/16/biblical-definitionof-modesty/

Gill, Michael B. (2006). The British moralist on human nature and the birth of secular ethics. Cambridge University Press.

Gill, J., \& Johnson, P. (2010). Research methods for managers (4th Ed.). London, UK: Sage. Gresh, D. (2007). The clothes crisis. Christian Parenting Today. Winter, 44-48. Retrieved from http://www.todayschristianwoman.com/articles/2002/december/4.44.html

Harman, J. (n.d.). Modesty: Virtue ignored contending for modesty in the church. PsychoHeresy Awareness Ministries. Retrieved from http://www.psychoheresyaware.org/modesty_ignored.html\#Part II

Human Rights Watch. (2009, February 26). Discrimination in the name of neutrality: 
Headscarf bans for teachers and civil servants in Germany. Retrieved from:

https://www.hrw.org/report/2009/02/26/discrimination-name-neutrality/headscarf-bansteachers-and-civil-servants-germany

Hume, L. (2013). The religious life of dress: Global fashion and faith. New York, NY: Bloomsbury.

Kaiser, S.B., Nagasawa, R.H. and Hutton, S.S. (1991). Fashion, postmodernity and personal appearance: A symbolic interactionist formulation. Symbolic Interaction, 14(2): 165-185.

Kawamura, Y. (2011). Doing research in fashion and dress: An introduction to qualitative methods. New York, NY: Berg.

Kayser, P. G. (2009). Dressed up for church?! A contrarian rag on appropriate clothing. Omaha, NE: Biblical Blueprints.

King, A. (2015). Iconic wear: When religion and fashion meets on the runway. Ethos. Retrieved from www.ethosreview.org/cultural-interventinos/iconic-wear-when-religion-andfashion-meet-on-the-runway/

Kite, L., \& Kite, L. (2015). Beauty redefined [Web log post]. Retrieved from http://www.beautyredefined.net/modest-is-hottest-the-revealing-truth/

Lewis, R. (2011). Modest dressing: Faith-based fashion and Internet retailing. Retrieved from http://www.arts.ac.uk/media/research/documents/LCF-Modest_DressingProject_Summary.pdf

Lewis, R. (2013). Modest Fashion: Styling Bodies, Mediating Faith. New York: Palgrave Macmillan.

LDS Church (2016) Dress and appearance. The Church of Jesus Christ of Latter Day 
Saints. Retrieved from: https://www.lds.org/youth/for-the-strength-of-youth/dress-andappearance?lang=eng

Mackay, S. (2013, September 23). Religious iconography in fashion [Web log post]. Retrieved from https://sarabadara.wordpress.com/2013/09/23/religious-iconography-in-fashion/

Mackinney-Valentin, M. (2013). Face value: Subversive beauty ideals in contemporary fashion marketing. Fashion, Style \& Popular Culture, Volume 1, Number 1, 1 October 2013, pp. 13-27(15). Intellect

Macmillan, A. (2013). Faith in fashion. Christianity Today. Retrieved from http://www.christiantoday.com/article/faith.in.fashion/35154.htm

Matthews David, A. (2015, September 22). How the fashion industry has injured women: From killer heels to long scarf syndrome. Independent. Retrieved from http://www.independent.co.uk/life-style/fashion/features/how-the-fashion-industry-hasinjured-women-from-killer-heels-to-long-scarf-syndrome-10513107.html

McMullin, I. (2010). A modest proposal: Accounting for the virtuousness of modesty. The Philosophical Quarterly. 60(241): 783-807. Oxford University Press. Retrieved from: https://www.jstor.org/stable/40926798?seq=1\#page_scan_tab_contents

Modesty. (n.d.). In Merriam-Webster.com. Retrieved from http://www.merriamwebster.com/dictionary/modesty

Mossière, G. (2012). Modesty and style in Islamic attire: Refashioning Muslim garments in a Western context. Contemporary Islam, 6(2), 115-134. doi:10.1007/s11562-011-0180-9

Moving Towards Modesty. (2010). What is Modesty? Retrieved from http://www.movingtowardmodesty.com/What-is-Modesty.html 
O'Cass, A., \& Julian C. C. (2001). Fashion clothing consumption: Studying the effects of materialistic values, self-image/product-image congruency relationships, gender and age on fashion clothing involvement. Retrieved from http://epubs.scu.edu.au/cgi/viewcontent.cgi?article=1388\&amp;context=comm_pubs Pew Research Center. (2012, December). The global religious landscape: A report on the size and distribution of the world's major religious groups as of 2010. Washington, DC: Author. Retrieved from http://www.pewforum.org/files/2014/01/global-religion-full.pdf

Pew Research Center. (2014). Religious landscape study: Religions. Washington, DC: Author. Retrieved from http://www.pewforum.org/religious-landscape-study/

Pollard, J. (2010a). A return to modest apparel. Modest Apparel, 216, 24-25. Retrieved from http://www.chapellibrary.org/files/8113/7658/4056/mappfg.pdf

Pollard, J. (2010b). Christian modesty defined. Modest Apparel, 216, 4-6. Retrieved from: http://www.chapellibrary.org/files/8113/7658/4056/mappfg.pdf

Religion and dress. (2009, October 7). In Encyclopedia of Clothing and Fashion. Retrieved from http://angelasancartier.net/religion-and-dress

Riggs, B. (2009). Modesty, clothing \& God. Truth According to Scripture. Retrieved from http://www.truthaccordingtoscripture.com/documents/articles/modestclothing.php\#.VuDUVHOrKt8

Robinson, D. E. (1999). Seventh-Day Adventists and the reform dress. (Original work published 1950). Retrieved from http://www.whiteestate.org/issues/Dressref.html

Schmidt, L. E. (1989). A church-going people are a dress-loving people: Clothes, communication, and religious culture in early America. Church History, 58(1), 36-51. 
Sermon Index. (2015). Judging other Christians by outward appearance. Retrieved from http://img.sermonindex.net/modules/newbb/viewtopic_pdf.php?topic_id=54561\&forum=34

Shalit, W. (1999). A Return to Modesty. New York: Free Press.

Shalit, W. (2000). Proud to be modest. Christianity Today, January 10, 70-71.

Shete, V. (2012). Fashion \& social identity: A cultural phenomenon [Web log post]. Retrieved from https://virshete.wordpress.com/2012/07/15/fashion-and-social-identity-a-culturalphenomenon/

Sociology Index (2002) Labelling theory. Retrieved from: http://sociologyindex.com/labeling_theory.htm

Spencer, R. (2010, June 16). Canada: Honor killing victim Aqsa Parvez's father and brother sentenced to life of prison dawah. Jihad Watch. Retrieved from http://www.jihadwatch.org/2010/06/canada-honor-killing-victim-aqsa-parvezs-fatherand-brother-sentenced-to-life-of-prison-dawah

Spinney, R. G. (2010a). Accessories to adultery. Modest Apparel, 216, 15-17. Retrieved from http://www.chapellibrary.org/files/8113/7658/4056/mappfg.pdf

Spinney, R. G. (2010b). Thinking like a Christian about modest apparel. Modest Apparel, 216, 24. Retrieved from http://www.chapellibrary.org/files/8113/7658/4056/mappfg.pdf

Spinney, R. G. (2010c). Too much, too little, too tight. Modest Apparel, 216, 19-22. Retrieved from: http://www.chapellibrary.org/files/8113/7658/4056/mappfg.pdf

Statistics Canada. (2011). National household survey: Immigration, place of birth, citizenship, ethnic origin, visible minorities, language and religion. Retrieved from http://www.statcan.gc.ca/daily-quotidien/130508/dq130508b-eng.htm?HPA 
Statistic Canada. (2014). Canadian demographics at a glance: Two-thirds of the population declare Christian as their religion. Retrieved from http://www.statcan.gc.ca/pub/91-003x/2014001/section03/33-eng.htm

Stone, R. M. (2014). The real meaning of modesty. Todays's Christian Woman. Retrieved from http://www.todayschristianwoman.com/articles/2014/may-week-4/real-meaning-ofmodesty.html

Summerfield, A, Summerfield, J. and Abdullah, T. (1999). Walk in splendor: Ceremonial dress and the Minangkabau. UCLA Fowler Museum of Cultural History.

Tarlo, E. (2007). Islamic cosmopolitanism: The sartorial biographies of three Muslim women in London. Fashion Theory, 11(2/3), 143-172.

Tarlo, E. (2010). Visibly Muslim: Fashion, Politics, Faith. Oxford: Berg.

Teddlie, C., \& Yu, F. (2007). Mixed methods sampling: A typology with examples. Journal of Mixed Methods Research, 1(1), 77-100. doi:10.1177/2345678906292430

The International Bible Society. (2014, January 15). The Bible: 1 Timothy. Zondervan. From Zondervan, NIV Study Bible. Retrieved from http://www.biblica.com/en-us/bible/onlinebible/scholar-notes/niv-study-bible/intro-to-1-timothy/

Wade, L. (2012). Defining women's oppression: The burka vs the bikini. The Society Pages. Retrieved from https://thesocietypages.org/socimages/2012/02/22/questioningdefinitions-of-freedom/

Washer, P. (2014, January 22). How a Christian woman is to adorn herself [Video file]. Retrieved from http://www.youtube.com/watch?v=4xbJhB7xqU8 wbauck. (2013, August 16). My cross to wear: Religious imagery in fashion [Web log post]. Retrieved from http://unwrinkling.com/my-cross-to-wear/ 
What does the Bible say about proper dress? (n.d.). In Christian Bible Reference Site. Retrieved from http://www.christianbiblereference.org/faq_dress.htm

Whelchel, L. (2005). Fashion-diva daughter: How can we get her to dress more modestly? Christian Parenting Today, Spring, 8-9.

Wilson Trower, V. (2004). Book review: Through the wardrobe: Women's relationships with their clothes, by A. Guy, E. Green, \& M. Banim). Fashion Theory, 8(3), 351-354. doi:10.2752/136270404778051672

Wood, A. G. (2011, August 24). Paul Washer on modesty [Web log post]. Retrieved from https://annawood.wordpress.com/2011/08/24/paul-washer-on-modesty/

Woodsmall, C. (2016) Why the Amish dress the way they do. Retrieved from: http://www.cindywoodsmall.com/2012/05/14/why-the-amish-dress-the-way-they-do/ 


\section{Bibliography}

Alzheimer Europe. (2009). Types of research: The four main approaches. Retrieved from http://www.alzheimer-europe.org/Research/Understanding-dementia-research/Types-ofresearch/The-four-main-approaches

ASCD. (n.d.). The purpose of education. Retrieved from http://www.ascd.org/ASCD/pdf/journals/ed_update/eu201207_infographic.pdf

Ashworth, P. (2012) Psychology and Human Nature. Routledge. Retrieved from: http://site.ebrary.com.ezproxy.lib.ryerson.ca/lib/oculryerson/reader.action?docID=10053 856

Davis, J. (2008). Fashion: Introduction, lifestyle, communication. Delhi, India: Abhishek Publications.

de Vaus, D. A. (1996). Surveys in social research (4th ed.). London, UK: UCL Press.

Entwistle, J. (2002). Book review: Fashion and its social agendas: Class, gender and identity in clothing, by D. Crane. Fashion Theory, 6(3), 331-334.

doi:10.2752/136270402790577622

Fundamentalist Baptist Church. (n.d.). Teaching Christian ladies to dress modestly. Retrieved from http://christiansdressingmodestly.com/

Hume, L. (2016). Dress and religion. Berg Fashion Library. Retrieved from http://www.bergfashionlibrary.com/page/Dress\$0020and\$0020Religion/dress-andreligion

Ingraham, L. (2011). Modesty guidelines. Retrieved from http://affiliate.purefashion.com/modesty

Lemay, R. (2015). Dress and adornment: Blessings of proper attire. Retrieved from 
https://text.egwwritings.org/publication.php?pubtype=Book\&bookCode=3SM\&pagenum ber $=241$

Lewis, R. (2013). Modest fashion: Styling bodies, mediating faith. London, UK: I.B. Tauris.

Litfin, D. (2012). Clothing matters: What we wear to church: why what we put on may be more important than we think. Christianity Today. Retrieved from http://www.christianitytoday.com/ct/2012/januaryweb-only/clothingmatters.html

Mossiere, G. (2011) Modesty and style in Islamic attire: Refashioning Muslim garments in a Western context. Published online: 9 November 2011 \# Springer Science+Business Media B.V. 2011: Retrieved from:

http://journals2.scholarsportal.info.ezproxy.lib.ryerson.ca/pdf/18720218/v06i0002/115_m asiiamgiawc.xml

Osterman, S. (2015). Dress: An issue of my heart. Adventists Affirm, 17(3). Retrieved from http://www.adventistsaffirm.org/article/118/previous-issues/volume-17-number-3/dressan-issue-of-my-heart

Pink, W.A. (2010). A crying sin of our age. Modest Apparel, 216, 6-9. Retrieved from http://www.chapellibrary.org/files/8113/7658/4056/mappfg.pdf

Research Design Service South West. (2016). Research Design Service South West. Retrieved from http://projects.exeter.ac.uk/prdsu/helpsheets/Helpsheet09-May03-Unlocked.pdf

Spurgeon, C. H. (2010). Our royal apparel. Modest Apparel, 216, 22-24. Retrieved from http://www.chapellibrary.org/files/8113/7658/4056/mappfg.pdf

Washer, P. (2014, January 22). How a Christian woman is to adorn herself [Video file]. Retrieved from http://www.youtube.com/watch?v=4xbJhB7xqU8 
What does the Bible say about proper dress? (n.d.). In Christian Bible Reference Site. Retrieved from http://www.christianbiblereference.org/faq_dress.htm 